\title{
Biotechnological Generation of Value Added Products from Spent Pulping Liquors: Assessing the Potential of Extremophiles
}

\author{
Michaela Weissgram $^{1,2}$, Christoph Herwig ${ }^{2}$ and Hedda K Weber ${ }^{1^{\star}}$ \\ ${ }^{1}$ Kompetenzzentrum Holz GmbH, Altenbergerstr. 69, 4040 Linz, Austria \\ ${ }^{2}$ Vienna University of Technology, Institute of Chemical Engineering, Research Area Biochemical Engineering, Gumpendorferstraße $1 A$, 1060 Vienna, Austria
}

\begin{abstract}
Carbon rich industrial waste streams are interesting raw materials for biorefineries, due to their high abundance and relatively low price. However, they are a challenging habitat for microorganisms, due to extreme $\mathrm{pH}$ and temperature levels, as well as high abundance of inhibiting substances. Extreme conditions call for extreme microorganisms.

This contribution aims to show the potential of extremophilic bioprocesses for the generation of valuable products from industrial waste streams on the example of the pulping waste streams spent sulfite liquor (SSL) and Black Liquor (BL). It provides an overview of products, which can be produced biotechnologically by extremophilic organisms and compares their performance to benchmark biotechnological processes. Furthermore it elucidates the factors to be considered for bioprocesses on industrial waste streams, thereby providing a toolset for selecting a bioprocess based on the waste stream. Finally bioprocesses are proposed for SSL and BL, two of which are already investigated in our workgroup.
\end{abstract}

Keywords: Extremophile bioprocesses; Chemical building blocks; Pulping waste streams; Waste to value

\section{Introduction}

Worldwide bio-economy concepts foster the conversion of biomass into a range of food, health, fiber, industrial products, and energy. However, there is a risk that the diversion of farmland or crops for the production of biofuels and bio-based products compromises the food supply-the food versus fuel dilemma. One way to circumvent this dilemma is the use of spent liquors from the pulping industry in terms of a wood biorefinery. The pulping process leads to a solid fraction mainly consisting of cellulose (pulp) and a liquid fraction containing a mixture of the other wood components and their degradation products, which can be further processed. The economical success of the utilization of these liquid fractions largely depends on an efficient separation and conversion of the organic compounds-predominantly the carbohydrates. Integrating biotechnological processes into existing pulp mills is expected to achieve those requirements. Employing extremophilic microorganisms, e.g. Acidothermophiles or Alkalithermophiles, in the bioprocesses could lead to further process intensifications by saving chemicals, cooling energy and sterilization steps.

In 2004 the US Department of Energy published a list of chemical building blocks, which are likely to become a commercial success [1]. This list was used as guidance for identifying promising target products for bioprocesses. In 2014 the Obama administration identified advanced materials including composites and bio-based materials as one of three technologies critical to U.S. competitiveness [2]. Therefore, biopolymers like polyhydroxyalkanoates or their precursors like lactic acid and succinic acid are included. And last but not least ethanol and butanol are considered, which can be used as chemicals or biofuels (Table 1).

This review article, therefore, summarizes

- a short description of the commercial pulping processes (Sulfite and Kraft) highlighting the parameters relevant for the bioprocessing
- the commercially realized processes yielding products from spent liquor

- $\quad$ target products accessible by bioprocesses, their (potential) markets and state of the art of the bioprocesses

- an overview of potential candidates (excluding GMOs) for future bioprocesses in the pulping industry with special emphasis on extremophiles

- two examples for employing extremophiles from our research

\section{The Commercial Pulping Processes}

Lignocellulose (wood) is composed of strands of cellulose molecules embedded in a matrix of hemicellulose and lignin. Hemicelluloses are plant heteropolysaccharides whose chemical nature varies from tissue to tissue and from species to species [3]. It can generally be assumed, that softwood hemicelluloses contain high amounts of mannose, whereas hardwood hemicelluloses contain high amounts of xylose.

In order to obtain chemical pulp the cellulose has to be separated from the other wood components. To date the two major commercial pulping processes are the Kraft process and the Sulfite process. Figure 1 summarizes the pulping conditions of both processes, the "pedigree" of the major organic components present in the spent liquors and a rough

*Corresponding author: Hedda KWeber, Vienna University of Technology, Institute of Chemical Engineering, Kompetenzzentrum Holz GmbH, Altenbergerstraße 69 4040 Linz, Austria, Tel: +43-(0)-732-2468-6773; Fax: +43-(0)-732-246-867-55; E-mail: h.weber@kplus-wood.at

Received June 26, 2015; Accepted July 16, 2015; Published July 21, 2015

Citation: Weissgram M, Herwig C, Weber HK (2015) Biotechnological Generation of Value Added Products from Spent Pulping Liquors: Assessing the Potential of Extremophiles. J Bioprocess Biotech 5: 241 doi:10.4172/2155-9821.1000241

Copyright: ( 2015 Weissgram M, et al. This is an open-access article distributed under the terms of the Creative Commons Attribution License, which permits unrestricted use, distribution, and reproduction in any medium, provided the original author and source are credited. 
estimate of the composition of the spent liquors (spent sulfite liquor = SSL and black liquor $=\mathrm{BL}$ ).

\section{Kraft process}

The Kraft process uses an aqueous solution of sodium hydroxide $(\mathrm{NaOH})$ and sodium sulfide $\left(\mathrm{Na}_{2} \mathrm{~S}\right)$ at elevated temperatures $(155-$ $\left.175^{\circ} \mathrm{C}\right)$, elevated pressure (7-10 bar) and $\mathrm{pH}$ values beyond 10 for the digestion of wood. It is the dominant pulping process in the pulp and paper industry. Kraft pulp accounts for two-thirds of the world's virgin pulp production and for over $90 \%$ of chemical pulp with a global production of about 130 million tons per year [4]. The compositions of the black liquors derived from hardwood and softwood, respectively, are shown in Table 2.

\begin{tabular}{|c|}
\hline Target molecule \\
\hline 1,3-propanediol ${ }^{2}$ \\
\hline 3-hydroxy propionic acid ${ }^{1}$ \\
\hline 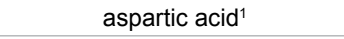 \\
\hline fumaric acid ${ }^{1}$ \\
\hline glucaric acid $^{1}$ \\
\hline itaconic acid ${ }^{1}$ \\
\hline lactic acid ${ }^{2}$ \\
\hline succinic acid $^{2}$ \\
\hline polyhydroxyalkanoates $(\mathrm{PHA})^{2}$ \\
\hline ethanol \\
\hline butanol \\
\hline sorbitol $^{1}$ \\
\hline xylitol \\
\hline
\end{tabular}

Table 1: Promising target products for the bioprocessing of spent pulping liquors [1].

\section{Sulfite process}

The Sulfite process uses an aqueous solution of acidic bisulfite at elevated temperatures $\left(130-160^{\circ} \mathrm{C}\right)$, elevated pressure (7-10 bar) and $\mathrm{pH}$ values ranging from 1-4 for the digestion of wood. The industrially used cations in the sulfite pulping processes are calcium, magnesium, sodium and ammonium. The generated spent liquor is called spent sulfite liquor (SSL) and contains dissolved solids such as lignosulfonates and hemicellulose hydrolysis products, which comprise about 40-50 g $\mathrm{l}^{-1}$ of hexoses and pentoses [5]. The composition of the sugar fraction in SSL depends on the type of wood used for pulping. Coniferous "soft" wood yields high proportion of hexose sugars (predominantly mannose and glucose), whereas deciduous "hard" woods yield a high proportion of the pentose sugar xylose. The compositions of the sulfite spent liquors derived from hardwood and softwood, respectively, are shown in Table 2

\section{State of the Art Spent Liquor Utilization}

To date the major use of spent liquors is energy generation and merely a handful of products are obtained: One strategy focuses on reducing the high fossil energy need by thermal utilization of the spent liquors. This has the advantage that the cooking chemicals can be recovered [6]. Pulp mills have used black liquor as an energy source since at least 1930 [7]. Recovery boilers are used to burn the black liquor to recover the chemicals sodium hydroxide and sodium sulfide, which are used to separate lignin from the cellulose fiber. Furthermore, they produce steam used for the generation of energy. This reduced problems with water emissions as well as the use of chemicals due to recovery and reuse. Spent sulfite liquors are treated accordingly. Therefore, paper mills are nearly energy self-sufficient by producing, on average, $66 \%$ of their own electricity needs on-site. Hence, the forest

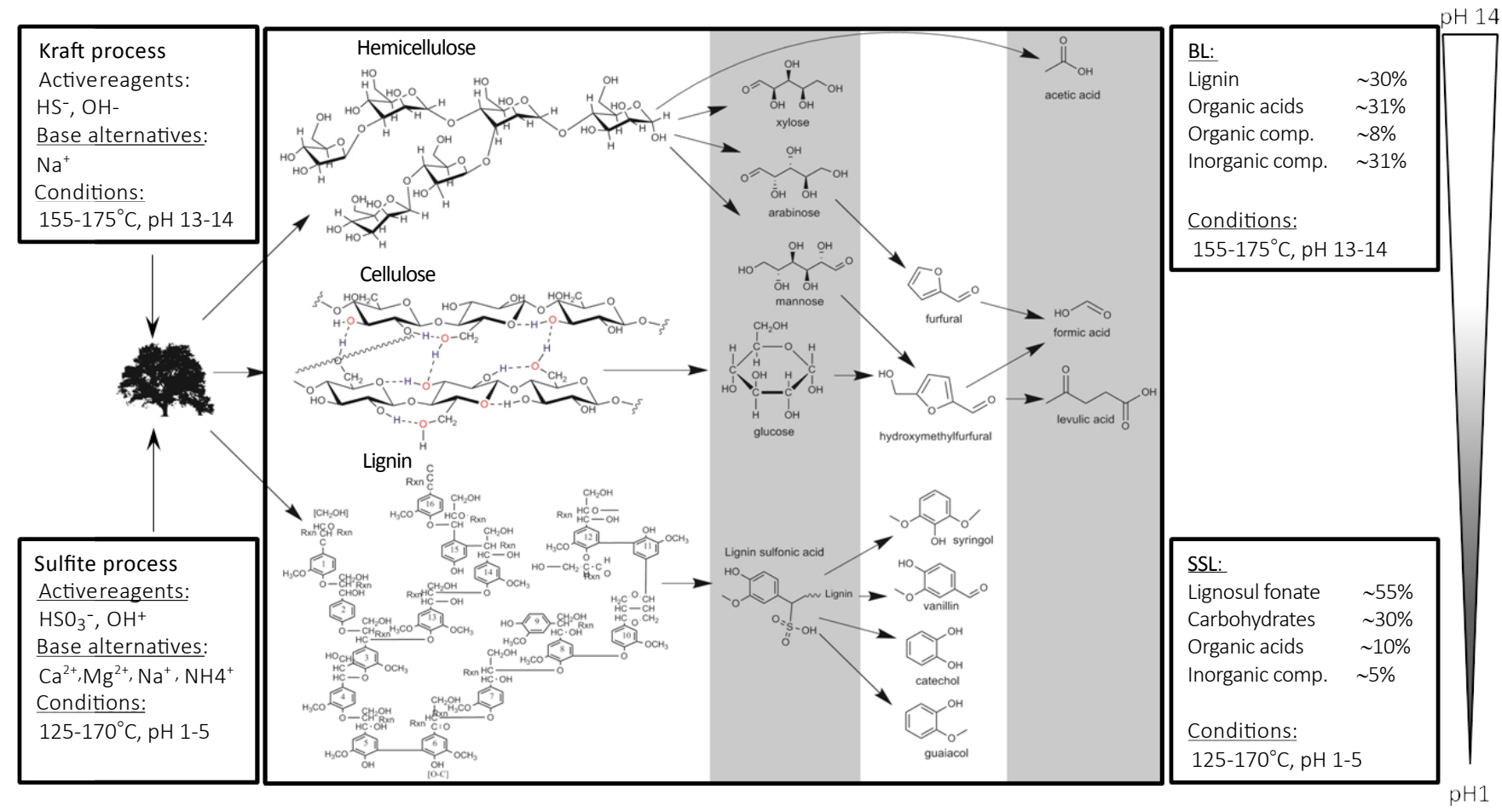

Figure 1: Process scheme of acidic and alkaline wood hydrolysis. 
Page 3 of 14

\begin{tabular}{|c|c|c|c|c|}
\hline & \multicolumn{2}{|c|}{ Kraft process } & \multicolumn{2}{|c|}{ Sulfite process } \\
\hline $\mathrm{pH}$ & \multicolumn{2}{|c|}{$13-14$} & \multicolumn{2}{|c|}{$1-4$} \\
\hline \multirow[t]{2}{*}{ temperature } & \multicolumn{2}{|c|}{$160-180^{\circ} \mathrm{C}$} & \multicolumn{2}{|c|}{$125-170^{\circ} \mathrm{C}$} \\
\hline & $\begin{array}{c}\text { Pine } \\
\% \text { w/w DM }\end{array}$ & $\begin{array}{c}\text { Birch } \\
\% w / w \text { DM }\end{array}$ & $\begin{array}{l}\text { Spruce } \\
\% \text { w/w DM }\end{array}$ & $\begin{array}{c}\text { Birch } \\
\% \text { w/w DM }\end{array}$ \\
\hline $\begin{array}{c}\text { Monosaccharides } \\
\text { arabinose }\end{array}$ & & & 1 & 0 \\
\hline galactose & & & 5 & 1 \\
\hline glucose & & & 4 & 1 \\
\hline mannose & & & 12 & 6 \\
\hline xylose & & & 6 & 21 \\
\hline $\begin{array}{l}\text { Organic acids } \\
\text { acetic acid }\end{array}$ & 4 & 9 & 4 & \\
\hline aldonic acids & & & 5 & \\
\hline formic acid & 6 & 4 & & \\
\hline glucuronic acid & & & & 2 \\
\hline glucoisosaccharinic acid & 7 & 3 & & \\
\hline glycolic acid & 2 & 2 & & \\
\hline lactic acid & 3 & 2 & & \\
\hline 2-hydroxybutanoic acid & 1 & 5 & & \\
\hline 3,4-dideoxy pentanoic acid & 2 & 1 & & \\
\hline 3-deoxypentanoic acid & 1 & 1 & & \\
\hline xyloisosaccharinic acid & 1 & 2 & & \\
\hline other acids & 4 & & & \\
\hline \multicolumn{5}{|l|}{ Others } \\
\hline lignin & 33 & 27 & & \\
\hline lignosulfonate & & & 55 & \\
\hline hemicellulose & 8 & 12 & & \\
\hline
\end{tabular}

Table 2: List of components in pulp and paper waste waters [105-107]

products industry is among the leading carbon-neutral industries using renewable energy.

The second strategy is to use the streams as biofuel feedstock for gasification, which has the potential to achieve higher overall energy efficiency than the conventional recovery boiler, while generating an energy-rich syngas from the liquor. The syngas can be burnt in a gas turbine combined cycle to produce electricity, or converted into chemicals or fuels such as methanol or dimethyl ether (DME). There is a 3 MW pilot plant under operation in Piteå, Sweden, where Chemrec runs tests on substrate from Smurfit Kappa for the production of BioDME. Since 2012 this BioDME plant constantly produces high quality DME that is used in trucks [8].

SSL has been used as a substrate for Single-Cell Protein (SCP) (Candida utilis or torula yeast) or alcohol production [9,10]: Yeasts have been used since the early $20^{\text {th }}$ century for the production of ethanol from Spent Sulfite Liquor (SSL). In 1909 the first sulfite ethanol plant opened in Skutskär, Sweden. Since then many of those plants had to close down because of the low fossil energy prices, the high costs for the substrate pretreatment and the inability of non-genetically modified yeasts to ferment the highly abundant C5-sugar xylose. Today merely a few companies are operating sulfite ethanol mills. Among them are Borregaard (Sarpsborg, Norway), Domsjø (Domsjø, Sweden), Tembec (Temiscaming, Quebec, Canada), Kirov (Kondopoga, Karelia, Russia), Kimberly- Clark (Everett Mill, USA) and Nippon Paper (Gutsu mill, Japan). Yeasts were also used to remove the carbohydrates from SSL in order to improve the quality of the lignosulfonates, which are sold as bulk chemicals. The pulp mill Biocel Paskov, for example, used Kluyveromyces fragilis, which was sold as fodder yeast under the brand name Vitex [11].

The chemical production of vanillin from SSL started in the 1930's with the in North America [12] and is nowadays mainly produced by Borregaard. The DuPont wood based process utilizes the SSL to chemically produce xylitol.

Kraft cooking of pine wood yields turpentine as well as tall oil, which is the only noteworthy product from black liquor and which is further processed to bulk chemicals. Additionally, small amounts of lignin are isolated from black liquors for chemical application. The carbohydratederived fractions, polysaccharides and aliphatic carboxylic acids, are currently not exploited due to scattered information on their chemical nature or composition, isolation and purification problems, as well as limited markets [13].

Generally, the use of microorganisms on black liquor and spent sulfite liquor has limitations. The carbohydrate fraction of SSL contains C6-sugars as well as C5-sugars derived from the hemicelluloses, whereas hardwood SSL contains a significantly higher portion of C5sugars than softwood SSL. Unfortunately, many microorganisms are only capable of fermenting hexoses, which lowers the overall efficiency and yield of the bioprocess. On the other hand, those microorganisms that can metabolize pentoses usually are less robust than their C6converting relatives. Black liquor is a challenging substrate since it only contains small amounts of carbohydrates and high amounts of organic acids, which can be utilized by very few strains. Furthermore, both spent liquors contain significant amounts of substances that are known for their inhibitory effects on microorganisms.

\section{Common substances in lignocellulose hydrolysates, known to inhibit microbial growth}

Several compounds of the lignocellulosic degradation products common in spent pulping liquors are known to inhibit microbial growth. Their effects on the microorganism have been widely discussed 
in the context of hydrolysates from the ethanol production, e.g. $[14,15]$. A general description of inhibitors found in lignocellulosic hydrolysates was published by Olsson and Hahn-Hägerdal in 1996 [16]. They were divided into four groups: furan derivatives, organic acids, phenols, and inorganic ions. The furan derivatives, furfural and hydroxymethyfurfural (HMF), are degradation products of pentoses and hexoses, respectively. Their inhibition mechanism is not fully clear.

Further degradation of the furan aldehydes leads to the generation of the organic acids formic acid and/or levulinic acid. Another organic acid namely acetic acid is a hydrolysis product derived from the hemicellulose fraction. Undissociated acids may pass through the cell membrane. They can dissociate inside the cell due to the neutral cytosolic $\mathrm{pH}$ value. The dissociation of the acids then lowers the $\mathrm{pH}$ in the cytosol, which may lead to cell death (Figure 2).

Phenolic derivatives are formed during the degradation of lignin. There is a large variety of structurally closely related phenols present, which renders their identification and quantification a challenging task. Various phenolic compounds have been found to inhibit cell growth
[17]. According to the literature the more hydrophobic a phenol is, the more harmful it is to cells $[18,19]$. The mechanism of toxicity of the phenolic compounds has not been elucidated in most cases. One theory suggests that the phenols interfere with the cell membrane, which will influence its function and change its protein-to-lipid ratio [20].

Inorganic ions may originate from the wood, the pulping chemicals, or the pulping equipment. Another source are the chemicals added for the adjustment of the $\mathrm{pH}$-value before the fermentation. A proposed inhibitory mechanism is osmotic stress [21]. Also, synergistic effects between the inhibiting substances have been proposed [19].

In a nutshell: the inhibitory effects of the furan derivatives, the organic acids, the phenols, and the inorganic ions are not yet fully understood, they are largely dependent on the concentration of the substances and vary with the respective microorganism. For the microbial production of other products than ethanol the available literature is yet rather limited. However, some detailed studies have been performed for T. mathranii, C. beijerinckii and a Bacillus strain.

The effect of wood degradation products such as salts, furfural,

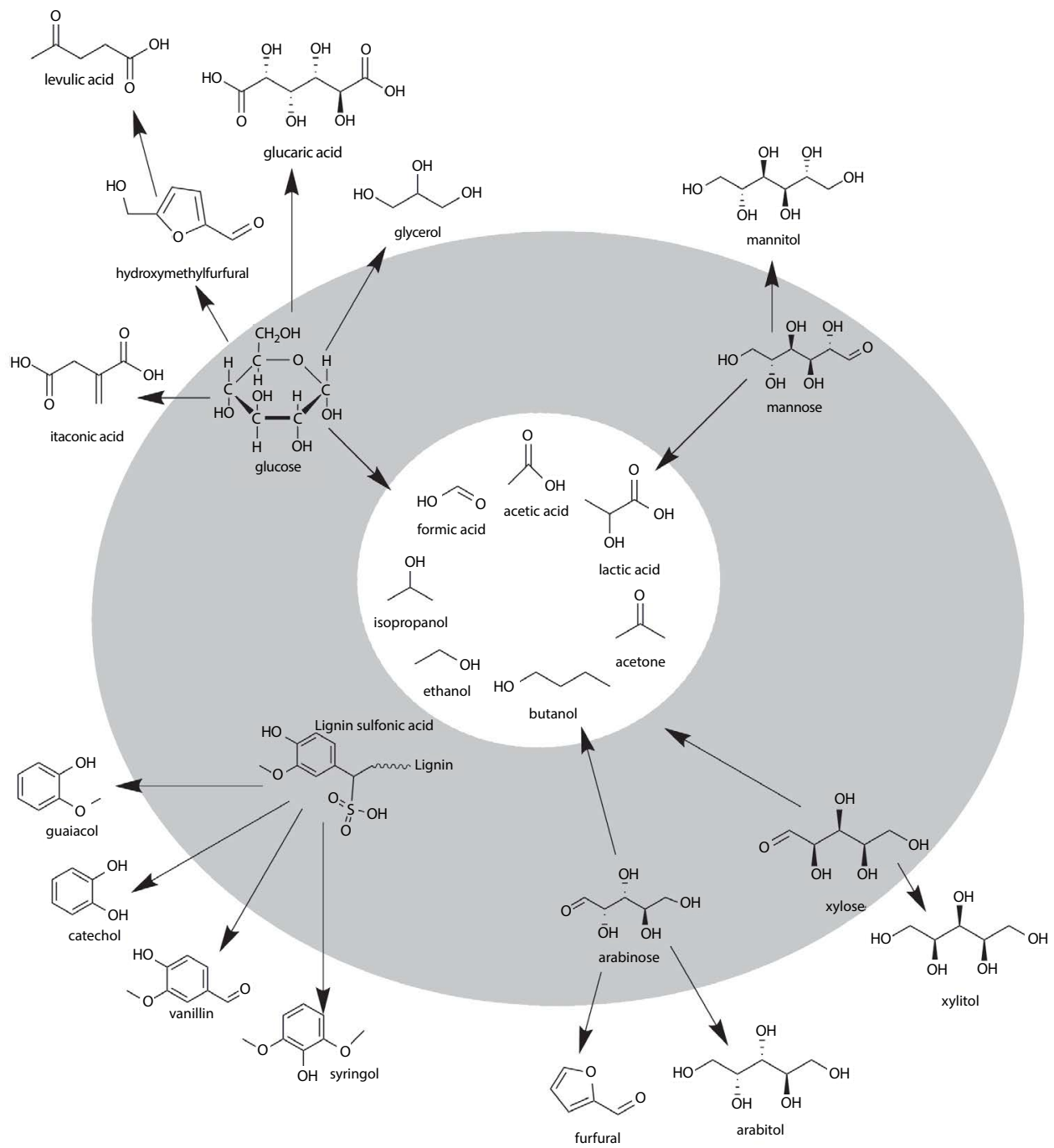

Figure 2: Chemicals (white circle) that can be prepared from precursors in lignocellulose (grey circle). 
hydroxymethyl furfural (HMF), syringealdhyde, and acetic, ferulic, $\rho$-coumaric, and glucuronic acids on cell growth and production of butanol has been investigated for C. beijerinckii [22]. While furfural, HMF, and acetic acid (as acetate) did not inhibit fermentation at the tested concentrations, ferulic and $\rho$-coumaric acids lowered cell growth and $\mathrm{ABE}$ production significantly.

A similar study was conducted for T. mathranii: nine phenols and 2 -furoic acid were each tested in concentrations of 10-100 times the concentration found in the hydrolysate for their effect on fermentation by $T$. mathranii. The study showed that the concentration of phenol aldehydes (4-hydroxybenzaldehyde, vanillin, syringaldehyde) higher than $10 \mathrm{mM}$ severely inhibited fermentation, while phenol ketones (4-hydroxyacetophenone, acetovanillone, acetosyringone, 4-hydroxybenzoic acid, vanillic acid, syringic acid) inhibited fermentation to a lesser extent [23].

Another study performed with a Bacillus strain (IFA 119) showed high inhibition by cinnamaldehyde, p-hydroxybenzaldehyde, and syringealdehyde, as well as for high levels of HMF and furfural (low concentrations had a stimulatory effect). Catechol and hydrochinone were the most toxic lignin derived components in this study; however, also iron (3+) and chromium (3+) were very toxic for the used strain.

These three studies show that for the investigated species phenols are very problematic. There are various strategies to overcome the inhibitory effects of phenolic components.

Several physicochemical methods have been proposed for the detoxification of the hydrolysates prior to the actual fermentation [24]. Proposed pretreatment steps include alkaline treatment [14], overliming, adsorption into activated charcoal and treatment with anion- and cation-exchange resins at different $\mathrm{pH}$ [25], or a nonionic polymeric adsorbent resin [26]. Salts can be successfully removed by electrodialysis [27]. Furthermore, total separation of lignosulfonates (LS) by an integrated process of ultrafiltration coupled to ion exchange or a membrane process can efficiently separate high molecular weight LS from the low-medium molecular weight LS and sugars [28].

A modified fermentation process may overcome the inhibition phenomena, for example, during a fed-batch process the inhibiting substances are added in small amounts below the inhibiting concentration. Finally the microorganisms themselves could be altered either by adaptive evolution $[29,30]$ or genetic engineering [31,32].

\section{Methods and Criteria for Microbial Utilization}

Sufficient amounts of carbohydrates need to be present and the organisms requirements for nitrogen, phosphor and sulfur supply as well as trace elements and vitamins need to be fulfilled for a substrate to be utilized by microorganisms. For this purpose the favored spent liquor has to be characterized. From a technological point of view there are factors that can be easily adjusted, like temperature and $\mathrm{pH}$, factors that can be changed with a considerable amount of effort, like amount of inhibitors and factors that cannot be changed at all, like the available substrates. Based on this evaluation a set of microorganisms, which can thrive on the chosen substrate can be identified.

Next, a portfolio of desired products is investigated, leading to a set of microorganisms capable of producing them. These two resulting sets of microorganisms (the one with the organisms able to thrive on the available substrate and the one with microorganisms producing desirable products) are compared and the intersecting set is identified.

The spent liquors present a substrate full of inhibiting substances, they leave the digesters with a high temperature and an extreme $\mathrm{pH}$-value and they contain a mixture of carbohydrates and their degradation products (Table 2). Therefore, organisms, which are able to withstand and thrive in these conditions, have to be identified. The main criteria for identifying strains suitable for biotechnological processes on pulping waste were determined according to their favored growing $\mathrm{pH}$ value, high temperature and utilization of at least cellulose, glucose, mannose, arabinose, galactose or xylose, but ideally also hemicelluloses. The most promising microorganisms for black liquor seem to be thermoalkaliphiles. However, the abilities to degrade oligosaccharides and organic acids will also be taken into account [33] The same decision criteria apply for fermentations on SSL. However, due to the low $\mathrm{pH}$ value of SSL thermoacidophile strains are favored.

\section{Microorganisms Generating Target Products}

Some of these products have been generated biotechnologically over a long period. In addition to ethanol, and butanol (1861, Louis Pasteur) 1,3-propanediol is probably among the oldest known fermentation products. It was reliably identified by August Freund in 1881, in a glycerol- fermenting mixed culture obviously containing Clostridium pasteurianum as an active organism [34]. Another well investigated process is the biotechnical production of succinic acid, which has been produced since the 1930's [35]. The following section lists target products accessible by bioprocesses, describes their (potential) markets and state of the art of the bioprocesses.

Where applicable, organisms, which are already used in a respective bioprocess, will be introduced as a benchmark for comparison to identified potential extremophile candidates. This benchmark organism can be an extremophile, but also a mesophile strain to show what an extremophile bioprocess has to compete with.

\section{3-Hydroxypropionic Acid and 1,3- propanediol}

The C3-building block 3-Hydroxypropionic acid (3-HP) is a valuable platform chemical, which can be produced biologically from glucose or glycerol [36]. By coupling the fermentation with chemical processing, this intermediate may then be used for the production of commercially valuable chemicals. Such chemicals include 1,3-propanediol, acrylic acid, malonic acid, and acryl amide, which are used in large quantities for adhesives, polymers, plastic packaging, fibers, and resins.

1,3-Propanediol (1,3-PDO) is an important chemical product, which can be used for synthesis reactions, in particular, as a monomer for polycondensations to produce polyesters, polyethers and polyurethanes [37]. It has been proposed by DuPont as a potential monomer for use in fibers for carpet for its improved dyeability and elasticity. So far only mesophilic organisms, including Clostridium ssp. [38,39] and Lactobacillus ssp. [40] species and genetically modified $E$. coli [41] have been reported to produce 1,3-PDO. Desulfovibrio sp., D. carbinolicus and $D$. fructosovorans can produce $3-\mathrm{HP}$ when growing on glycerol $[42,43]$. However no extremophiles producing 3-HP have been found. A benchmark organism for the production of 3-HP and 1, 3-PDO can be seen in Table 3 .

\section{Aspartic acid}

Major amounts of L-aspartic acid are used for the production of the sweetener aspartame. Furthermore it is used as educt for the stereo selective synthesis of many chiral organo-chemical molecules, such as polyene macrolide class antibiotics [44]. $\mathrm{N}$-substituted polyaspartic acid esters are used as reactive components in modern lacquer systems 


\begin{tabular}{|c|c|c|c|c|c|}
\hline Product & Strain & $\underset{\mathrm{Cmol}_{\mathrm{i}}\left(\mathrm{Clmol}_{\mathrm{s}}\right)^{-1}}{\mathbf{Y}_{\mathrm{s}}}$ & C-Source & References & Notes \\
\hline 1,3 - PDO & Clostridium diolis & 0.71 & glycerol & [108] & $w t / B M$ \\
\hline 3-HP & Lactobacillus reuteri & 0.914 & glycerol & {$[40,109]$} & wt/BM \\
\hline L-aspartic acid & E. coli EAPc-7 & & ammonium fumarate & [46] & $\begin{array}{l}\mathrm{GMO} / \mathrm{BM} \\
\mathrm{pH} 8.9\end{array}$ \\
\hline \multirow[t]{3}{*}{ Fumaric acid } & Rhizopus sp & & glucose & {$[50,51]$} & wt/BM \\
\hline & $\begin{array}{l}\text { Alkalibacterium } \\
\text { subtropicum }\end{array}$ & & glucose & [110] & $\begin{array}{l}\text { alkali- } \\
\text { halophile }\end{array}$ \\
\hline & Alkalibacterium gilvum & & glucose & [111] & $\begin{array}{l}\text { alkali- } \\
\text { halophile }\end{array}$ \\
\hline Glucaric acid & E. coli & & glucose & [112] & GMO/BM \\
\hline Itaconic acid & A. terreus & 0.94 & glucose & [113] & ME/BM \\
\hline \multirow[t]{6}{*}{ Lactic acid } & Lactobacillus pentosus & 0.435 & hydrolyzed wheat straw & {$[57]$} & ME/BM \\
\hline & Bacillus sp. 36D1 & & $\begin{array}{c}\text { sugar cane hemicellulose } \\
\text { hydrolysate }\end{array}$ & [114] & $\begin{array}{l}\text { acidophile, } \\
\text { thermotolerant }\end{array}$ \\
\hline & Bacillus sp. XZL4 & 0.98 & corn stover hydrolysate & [115] & thermophile \\
\hline & $\begin{array}{l}\text { Marinilactibacillus } \\
\text { psychrotolerans }\end{array}$ & 0.99 & glucose & [116] & halophile \\
\hline & $\begin{array}{l}\text { Alkalibacterium } \\
\text { subtropicum }\end{array}$ & & glucose & [110] & $\begin{array}{l}\text { alkali- } \\
\text { halophile }\end{array}$ \\
\hline & Alkalibacterium gilvum & & glucose & [111] & $\begin{array}{l}\text { alkali- } \\
\text { halophile }\end{array}$ \\
\hline \multirow[t]{2}{*}{ Succinic acid } & $\begin{array}{l}\text { Actinobacillus } \\
\text { succhinigenes }\end{array}$ & 0.91 & glucose & {$[117,118]$} & wt/BM \\
\hline & $\begin{array}{l}\text { Clostridium } \\
\text { thermosuccinogenes }\end{array}$ & 0.43 & inulin, fructose & {$[119,120]$} & $\begin{array}{l}\text { thermo } \\
\text {-phile }\end{array}$ \\
\hline \multirow[t]{4}{*}{ PHA } & Ralstonia Eutropha & $0.76 \mathrm{~g} \mathrm{~g} \mathrm{~g}^{-1}$ & palm oil, soybean oil & [121-124] & BM \\
\hline & Haloferax mediderranei & $\begin{array}{c}0.33 \mathrm{~g} \mathrm{~g}^{-1} \\
0.9 \mathrm{~mol} \mathrm{~mol}^{-1}\end{array}$ & $\begin{array}{l}\text { starch } \\
\text { glycerol } \\
\text { whey }\end{array}$ & {$[97,125-127]$} & halophile \\
\hline & Halomonas boliviensis & $0.1 \mathrm{~g} \mathrm{~g}^{-1}$ & hydrolyzed wheat bran & {$[99,128]$} & halophile \\
\hline & Halomonas elongata & & $\begin{array}{l}\text { glucose, mannose, xylose } \\
\text { SSL }\end{array}$ & {$[99,100,129,130]$} & halophile \\
\hline $\begin{array}{l}\text { BM } \\
\text { GMO } \\
\text { ME } \\
\text { wt }\end{array}$ & \multicolumn{5}{|c|}{$\begin{array}{c}\text { - benchmark organism } \\
\text { - genetically modified organisms } \\
\text { - metabolic engineering } \\
\text { - wild type organism, mesophile }\end{array}$} \\
\hline
\end{tabular}

Table 3: Summary of microorganisms producing organic acids and interesting bulk chemicals.

[45]. L-aspartic acid is also used as part of infusion solutions, for parenteral nutrition and for salification. To date it is only produced by mutant strains utilizing specific substrates like ammonium fumarate instead of simple sugars $[46,47]$.

\section{Fumaric acid}

Fumaric acid is used as a food additive, in beverages and baking powders mainly regulating acidity. It substitutes tartaric acid and occasionally replaces citric acid. Furthermore it is used in the manufacture of polyester resins and polyhydric alcohols and as a mordant for dyes. Currently, fumaric acid is produced chemically from maleic anhydride, which in turn is produced from butane [48]. With rising petroleum prices, maleic anhydride as a petroleum derivative has increased in price as well, renewing the interest in fumaric acid production by fermentation as was operational during the 1940 s [49]. Although the chemical process yields $112 \% \mathrm{w} / \mathrm{w}$ fumaric acid from maleic anhydride and the fermentation process yields only $85 \%$ $w / w$ from glucose, the latter raw material is three times cheaper [48]. Additionally, the fermentation fixes $\mathrm{CO}_{2}$, a fact that can be crucial in terms of $\mathrm{CO}_{2}$-neutrality of a process. Production of fumaric acid by Rhizopus species and the involved metabolic pathways have been reviewed in literature [48]. So far mainly Rhizopus sp. [50,51] is known to be industrially interesting fumaric acid producers, thereby being the benchmark organism. Several extremophiles have been reported to produce at least trace amounts of fumarate [52], however the biotechnological feasibility and yield has not been reported so far.

\section{Glucaric acid}

Glucaric acid is a starting material for polymers like poly(hexamethylene glucaramide). No wild type microorganism is known to produce glucaric acid, however, several genetically engineered microorganisms were designed to produce glucaric acid.

\section{Itaconic acid}

Itaconic acid (IA) is an unsaturated dicarboxylic acid. It can easily substitute acrylic or methacrylic acid in polymers. It is used at $1-5 \%$ as a co-monomer in resins, in the manufacture of synthetic fibers, in coatings, in adhesives, and also in thickeners and binders [53]. The favored production process is the fermentation of carbohydrates by fungi (mainly Aspergillus sp.), with a current market volume of about $15,000 \mathrm{t} \mathrm{a}^{-1}$ [53]. At present, the production rates using A. terreus do not exceed $1 \mathrm{~g} \mathrm{l}^{-1} \mathrm{~h}^{-1}$, and product concentrations of about $80 \mathrm{~g} \mathrm{l}^{-1}$ [53], The achieved titers for itaconic acid are still low. Furthermore, purified substrates are required for optimal productivity, making the overall process expensive. Due to the high price of about 4 USD $\mathrm{kg}$ ${ }^{1}$, the use of itaconic acid is restricted [53]. A productivity of $2.5 \mathrm{~g} \mathrm{l}^{-1}$ 
$\mathrm{h}^{-1}$ was proposed for the process to be economically competitive [1]. Fermentations are run below $\mathrm{pH} 3.5$ and the strain can, therefore, be considered an extremophile [54].

\section{Lactic acid}

Lactic acid is commonly used in food, pharmaceuticals and cosmetics. In the last years the interest in its use for the production of poly-lactic acid (PLA), a biobased polymer with properties of a thermoplast, has grown. An ideal lactic acid-producing strain converts the substrate fast and complete, with high yields of preferred stereospecific lactic acid under low $\mathrm{pH}$ value and high temperature conditions. Preferred raw materials are common, cheap carbon sources like sucrose, lactose, starch, or sulfite waste liquor, which are fermented by numerous species of the genus Lactobacillus [55]. L. amylophylus and L. amylovirus are able to ferment starch, L. lactis can ferment glucose, sucrose and galactose and $L$. pentosus have been used to ferment sulfite waste liquor [56]. Using acid hydrolyzed wheat straw, a yield of 0.435 $\mathrm{Cmol}(\mathrm{Cmol})^{-1}$ lactic acid could be observed in L. pentosus [57], thereby posing as benchmark organism. However, several extremophile, mainly halophilic lactic acid bacteria have been identified. A summary of these bacteria is listed in Table 3 .

\section{Succinic acid}

Nowadays, the succinic acid market is about 20000-30000 ton per year worldwide and is manufactured on industrial scale by catalytic hydrogenation of petrochemically derived maleic acid or maleic anhydride [58,59]. The four existing succinic acid markets are the detergent/surfactant market, the ion chelator market, food market (e.g. acidulants, flavors or antimicrobials) and the pharmaceutical market [60]. These markets have high added value and do not require very cheap feedstock [61]. However, succinic acid derived commodity chemicals like butanediol (BDO), tetrahydrofuran (THF) and gammabutyrolactone (GBL) are mostly low cost bulk chemicals [60]. In order to compete with products derived from petrochemicals, the fermentation cost needs to be at or below $\$ 0.25$ per pound. A minimum productivity of $2.5 \mathrm{~g} \mathrm{l}^{-1} \mathrm{~h}^{-1}$ needs to be achieved in order to make the bioconversion process economically competitive [1]. Several microorganisms have been proposed for biotechnological succinic acid production, some are shown in Table 3.

\section{Polyhydroxyalkanoates}

Polyhydroxyalkanoates (PHA) are biobased polyesters that can be produced directly via single step bioprocesses fermenting carbon sources from renewable feedstocks. The PHA serves as a microbial energy reserve material that is stored as granules within the cytoplasm of the cell and created, once the nutrients are reduced to create an imbalance, which puts the microorganisms under stress. Under ideal conditions, typically, from $80 \%$ to $90 \%$ of the cell weight can comprise PHA. Technologically PHA has highly attractive qualities for thermo-processing applications as bioplastics and their mechanic characteristics are similar to polypropylene [62].

At the moment there are several companies that provide a large scale PHA based product. Metabolix Inc.,which produces PHA latex that is derived from renewable raw materials and can be used to replace $\mathrm{PE}$ as moisture-resistant barrier coatings for paper and corrugated cardboard applications, is planning to establish an intermediate-scale manufacturing capacity of 2.5 to 5.0 kilo tons per year in late 2015 (Quarter Report Sept. 2014). Other companies are TianAn, producing about 2000 t. $\mathrm{p}$ a. of $\mathrm{PHB} / \mathrm{V}$ or Meredian. Typical PHA producing strains can be found in Table 3 .

\section{Butanol}

Similarly to ethanol, butanol is a solvent regularly produced by microorganisms during the $\mathrm{ABE}$ fermentation, named after the main products acetone, butanol and ethanol. It has various uses, including the use as a solvent in dyes, the use as a fuel and various applications in the polymer industry.

As a biofuel, bio-butanol shows even greater potential than bioethanol in the transportation industry as it contains $25 \%$ more energy than bioethanol (per volume). Microbial production of butanol is well documented and a variety of strains are available. Most commonly the used substrate is a monosaccharide, but some microorganisms are also able to utilize lactate [63]. Selected strains are listed in Table 4.

\section{Ethanol}

Alcoholic beverages produced by microbes are probably the oldest biotechnological processes used by mankind. Since the invention of the Otto engine in the 1860's ethanol has been successfully used as a fuel. However it is also an important industrial ingredient and has widespread use as a base chemical for other organic compounds, including ethyl esters, diethyl ether, acetic acid, ethyl amines, and, to a lesser extent, butadiene. Furthermore it is an excellent water soluble solvent and has a variety of medical uses. The annual worldwide production was about 21,812 Million U.S. gallons in 2012 [64]. Prices for ethanol vary widely, ranging from $2.3 \$$ /gal for bulk vendors at the stock market to high prices for ultra-pure analytical ethanol.

The production of ethanol by microorganisms has been excessively reviewed before [65-69]. Therefore, only a small variety of the most prominent extremophilic, especially thermoacidophilic candidates is mentioned in Table 4.

\section{Sorbitol}

Sorbitol is of increasing industrial interest as a sweetener, humectant, texturizer and softener [70]. Further applications include pharmaceutical products, sorbose, ascorbic acid, propylene glycol [71], synthetic plasticizers [72] and alkyd resins [73], among others. According to a market report sorbitol demand was 1,699.7 kilo tons in 2011 and is expected to reach 2,148.9 kilo tons in 2018 [74]. Liquid sorbitol presently dominates the product market and accounted for $83.3 \%$ of the overall demand in 2011 [74]. At present, it is produced chemically [75]. The mesophile bacterium Zymomonas mobilis is able to produce sorbitol and gluconic acid from fructose and glucose [76]. Furthermore sorbitol production has been described in Candida boidinii [77] and Candida famata [78], however no extremophile microorganism could be identified.

\section{Xylitol}

Xylitol is a sugar alcohol with an increasing global market potential. It has beneficial health properties and is used as a nutritive sweetener and food additive [79]. Its major use is for the prevention of dental caries, as xylitol prevents the growth of microorganisms responsible for tooth decay. Increasing commercial demand and scientific interest in xylitol has led to a demand of more than 125,000 tons per year for this product, with a value that is relatively high (4.5-

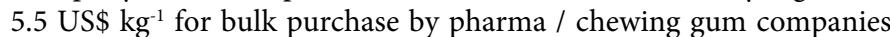
20 US $\$ \mathrm{~kg}^{-1}$ in supermarkets) makes it an attractive proposition for commercialization [80]. Several microorganisms have been reported to produce considerable amounts of xylitol. An exhaustive screening, investigating xylitol production was performed on 128 yeasts, resulting in several promising candidates. Among them are several strains of $S$. 


\begin{tabular}{|c|c|c|c|c|c|}
\hline Product & Strain & $\mathrm{Cmol}_{\mathrm{i}}\left(\mathrm{Y}_{\mathrm{p} / \mathrm{s}}\right.$ & C-Source & References & Notes \\
\hline \multirow[t]{5}{*}{ Butanol } & Clostridium acetobutylicum & 0.55 & glucose & [31] & wt/BM \\
\hline & & 0.23 & $\mathrm{SO}_{2}$-ethaol-water hydrolyzed spruce & [131] & $w t / B M$ \\
\hline & $\begin{array}{c}\text { Clostridium } \\
\text { thermosaccharolyticum }\end{array}$ & & $\begin{array}{c}\text { starch, glucose } \\
\text { oak saw dust hydrolysate } \\
\left(1 \% \mathrm{H}_{2} \mathrm{SO}_{4}\right)\end{array}$ & $\begin{array}{l}{[132]} \\
{[133]}\end{array}$ & thermo-phile \\
\hline & Hypothermus butylicus & & starch & [52] & thermo-phile \\
\hline & Pyrodictum abyssi & & carbohydrates & {$[134,135]$} & thermo-phile \\
\hline \multirow[t]{23}{*}{ Ethanol } & Caldicellulosiruptor sp. & & lignocellulose & [136] & thermo-phile \\
\hline & Caloramata boliviensis & $0.52-0.6$ & sugarcane bargasse hydrolysate & {$[137,138]$} & thermo-phile \\
\hline & Clostridium thermocellum & 0.35 & cellulose & {$[139,140]$} & thermo-phile \\
\hline & & 0.32 & filter paper & [141] & thermo-phile \\
\hline & & 0.30 & pretreated wood & [142] & thermo-phile \\
\hline & $\begin{array}{c}\text { Clostridium } \\
\text { thermosaccharolyticum }\end{array}$ & 0.39 & $\begin{array}{l}\text { oak saw dust hydrolysate } \\
\qquad\left(1 \% \mathrm{H}_{2} \mathrm{SO}_{4}\right)\end{array}$ & [133] & thermo-phile \\
\hline & Bacillus stearothermophilus & 0.36 & sucrose & [143] & thermo-phile \\
\hline & $\begin{array}{c}\text { Geobacillus } \\
\text { stearothermophilus }\end{array}$ & & $\begin{array}{l}\text { glucose, xylose, } \\
\text { arabinose, starch }\end{array}$ & {$[144,145]$} & thermo-phile \\
\hline & $\begin{array}{c}\text { Geobacillus } \\
\text { thermoglucosidasius }\end{array}$ & & $\begin{array}{l}\text { glucose, xylose, } \\
\text { cellulose, starch }\end{array}$ & {$[144,146]$} & thermo-phile \\
\hline & & $0.5-0.55$ & glucose & [147] & ME \\
\hline & Thermoanaerobacter AK5 & 0.42 & wheat straw hydrolysate & [148] & wt isolate \\
\hline & Thermoanaerobacter brockii & 0.29 & glucose & {$[149,150]$} & thermo-phile \\
\hline & $\begin{array}{c}\text { Thermoanaerobacter } \\
\text { ethanolicus }\end{array}$ & 0.63 & glucose & {$[151,152]$} & in test tubes \\
\hline & & 0.55 & xylose & [153] & batch \\
\hline & & 0.27 & birch wood hydrolysate & [154] & batch \\
\hline & & 0.29 & beet molasses & [155] & in test tubes \\
\hline & $\begin{array}{c}\text { Thermoanaerobacter } \\
\text { mathranii }\end{array}$ & $0.49 / 0.59$ & glucose & {$[136,156,157]$} & wt/GMO \\
\hline & & $0.55 / 0.56$ & xylose & [157-159] & wt/GMO \\
\hline & & $0.6 / 0.64$ & mannitol & [157] & wt/GMO \\
\hline & & 0.19 & wet oxidized wheat straw & [160] & in test tubes \\
\hline & & 0.38 & wet oxidized wheat straw & [23] & in test tubes \\
\hline & $\begin{array}{c}\text { Thermoanaerobacter } \\
\text { pseudoethanolicus } \\
\text { (C. thermohydro-sulfuricum) }\end{array}$ & 0.65 & glucose & [161-164] & $\begin{array}{l}\text { in test tubes } \\
\text { thermo-phile }\end{array}$ \\
\hline & $\begin{array}{c}\text { Thermoanaerobacter } \\
\text { saccharolyticum }\end{array}$ & 0.61 & xylose & [165] & ME \\
\hline Sorbitol & Zymomonas mobilis ZM31 & 0.162 & fructose, sucrose & [76] & $\mathrm{BM}$ \\
\hline \multirow[t]{3}{*}{ Xylitol } & Candida guilliermondii & 0.83 & xylose & [166] & BM \\
\hline & Debaryomyces hansenii & 0.507 & hydrolyzed brewery waste & [25] & osmo-tolerant \\
\hline & Gluconobacter oxydans & 0.98 & D-arabitol +D-glucose $+\mathrm{EtOH}$ & [167] & BM \\
\hline
\end{tabular}

rouxii, S. acidifaciens, $P$. farinosa, Hansenula anomala, $H$. suaveolens, Endomycopsis chodatii, C. melibiosii and Cryptococcus neoformans [81]. Furthermore the osmotolerant yeast D. hansenii is capable of xylitol production [82].

\section{Biotechnological Production of High Value Products from Spent Liquors}

As shown in previous chapters, various bioprocesses used for the generation of value added products have been identified. In this chapter we evaluate which microorganisms could ferment pulping spent liquors.

\section{Microorganisms Potentially Capable of Producing Desirable Products from Black Liquor (BL)}

The goal of this chapter is to suggest microorganisms capable of producing desirable products that are promising candidates to utilize sugars and organic acids in BL. The main monosaccharide units in the hemicellulose fraction of black liquor include the pentoses as arabinose, and xylose, with only some glucose and mannose, depending on the used wood. The total amount of hemicellulose is about $8 \%(\mathrm{w} / \mathrm{w})$ of dry matter, as shown in Table 2, whereas $31 \%$ of the dry matter comprise of organic acids. Therefore, processes utilizing pentoses and organic acid substrates are of interest. Since xylose is the predominant C5-sugar in hardwood xylitol production from hardwood BL is an interesting option. Butanol and ethanol can be fermented from various monosaccharides. However, the utilization of organic acids is limited. Some microorganisms are able to ferment organic acids to gaseous products; some bacteria isolated from the human colon are able to ferment organic acids to butyrate when they are deprived of sugars [63]. In an example for production of organic acids from Black Liquor (BL) citric acid was produced by $C$. tropicalis at concentrations of up to $15 \%$ $\mathrm{BL}$ in medium. However, higher concentrations of $\mathrm{BL}$ inhibited growth and production [83-85]. Generally a low $\mathrm{pH}$ value is preferable for the 
production of organic acids, making BL a suboptimal option [86]. Furthermore several halophilic microorganisms have been reported to utilize organic acids $[41,70,87]$. A group of halophilic microorganisms, belonging to genus Marinilactibacillus, is able to produce lactic acid at alkaline conditions [88].

As shown in Table 5 some processes show potential of generating high value compounds from BL, however, most of these processes are favored at neutral $\mathrm{pH}$ values. Only the generation of glycerol by the osmotolerant yeast $H$. anomala was reported to be independent of $\mathrm{pH}$ in a range from 5.4-8.6 [89]. Fermentation of xylose yielding xylitol is feasible at $\mathrm{pH} 8$, also minimizing the necessary change in $\mathrm{pH}$ of substrate BL. Although these organisms are known to be halotolerant, the high levels of salts and inhibitors in the BL make dilution or pretreatment necessary. An interesting option would be the alkalihalophile lactic acid bacteria. Another interesting option would be halophilic bacteria and Archaea. Not only could they be able to withstand the high salt load in BL, but they have also been reported to utilize a wide range of organic acids (acetate [90,91], lactate [92], formate [93,94]) and even some phenols [95]. Furthermore they produce a wide spectrum of high value products, among others the compostable bioplastic polyhydroxybutyrate (PHB) $[96,97]$ or the osmolytes ectoine $[98,99]$ and betaine [98]. Although so far no bioprocesses with Halophiles utilizing black liquor have been published, several experiments on wood hydrolysate and common inhibiting substances performed in our group could show that they are able to utilize SSL at commonly reported concentrations of $5-15 \%[\mathrm{w} / \mathrm{w}]$ dry matter [85]. The results of these experiments were published recently [100]

\section{Microorganisms Producing Desirable Products from SSL}

The goal of this chapter is to suggest microorganisms capable of producing desirable products that are promising candidates to adapt to growth on SSL. The main monosaccharide units in the polysaccharide fraction of spent sulfite liquor include mannose, glucose and xylose, with only some arabinose and galactose, depending on the wood used. As described before, butanol and ethanol, as well as organic acids can be fermented from various monosaccharides. In addition, xylitol production is an interesting use for process streams with high amounts of xylose. The relatively high abundance of glucose would also enable the production of sorbitol and itaconic acid. Furthermore, suitable strains should be able to thrive and produce at elevated temperatures and low $\mathrm{pH}$ values. Fermentation at low $\mathrm{pH}$ values can increase ethanol production, as for example ATP from ethanol production is needed for the plasma membrane ATPase in yeast, which pumps protons out of the cell to neutralize the inflow of weak acids [86]. Experiments on C. saccharoperbutylacetonicum have shown that presence of acetic acid shifts ABE production from butanol to acetone, whereas addition of butyric acid favors butanol production [101]. Furthermore it has been shown, that the maximal butanol production on a glucose limited culture of C. acetobutylicum DSM 1731 was achieved at a $\mathrm{pH}$ value around $\mathrm{pH} 4.3$ and that a $\mathrm{pH}$ value below 4.7 was necessary to show any butanol production [83].

As shown in Table 6 several microorganisms are promising candidates for the production of high value products from spent sulfite liquor (SSL). Especially among the ethanol producing microorganisms several extremophiles can be found. The possibility of processintegrated product purification, when producing ethanol at elevated temperatures, is a very interesting option and explains why these microorganisms are of high scientific interest. Most of the candidates are mesophiles, tolerant to $\mathrm{pH}$ values as low as $\mathrm{pH}$ 4. Among the yeasts several osmotolerant species are found. This is very important, due to the high salt load of SSL. The osmotolerant yeast $D$. hansenii is an ideal candidate for xylitol production at various $\mathrm{pH}$ values. It can produce xylitol and ethanol at $\mathrm{pH} 2-8$, with an optimum for glycerol production at $\mathrm{pH}$ 4.5-5.5 and an optimum for ethanol production at $\mathrm{pH}$ 6.58 [102]. For SSL with $\mathrm{pH}$ values lower than 4 a shift in $\mathrm{pH}$ will be necessary for most biotechnological processes. Although this can easily be implemented, it can lead to elevated salt levels, which can in return inhibit microbial growth. Hence, in the majority of the mentioned cases pretreatment cannot be avoided.

\section{Work from our Group}

Putting our concept to the test we investigated two types of extremophiles -Thermoacidophiles and Halophiles - for the production of ethanol and polyhydroxyalkanoates, respectively. Their $\mathrm{pH}$-range, temperature range and substrate spectrum (glucose, mannose, galactose, xylose and arabinose) were investigated. They could ferment all sugars at $65^{\circ} \mathrm{C}$ and a $\mathrm{pH}$ of 5 in the area of the Thermophiles and at high salt concentrations at $30^{\circ} \mathrm{C}$ and neutral $\mathrm{pH}$ in the case of the Halophiles and were able to produce the targeted products on dilutions of industrial SSL, containing 10-12 g of hydrolyzed sugar (2-6\% referring to solid content of the SSL) The detailed results for the thermophilic ethanol production are in preparation, whereas the results for halophilic PHB production were recently published [100].

\section{Conclusion and Outlook}

Research on the sustainable production of bio- fuels, bio- chemicals and bio- materials is always accompanied by the discussion of fuel versus food, and hence also by the search for ethically justifiable raw materials. Carbon rich waste streams have, therefore, been an interesting and cheap option for decades. However, decades of research have shown, that industrial waste streams are always challenging substrates for bioprocesses due to their extreme $\mathrm{pH}$ and temperature levels, as well as high abundance of substances inhibiting microbial growth. Extreme conditions call for extreme microorganisms. This contribution aims to show the potential of extremophilic bioprocesses for the generation of valuable products from industrial waste streams on the example of the pulping waste streams spent sulfite liquor (SSL) and black liquor (BL). One part of this contribution contains an overview of products, which can already be biotechnologically produced by extremophilic organisms. Additionally it shows how well they perform in comparison to benchmark biotechnological processes, often performed by their mesophile cousins, thereby presenting the general potential of extremophilic generation of various bio-chemicals.

Furthermore, the contribution elucidates the factors to be considered for bioprocesses on industrial waste streams. While some factors are a go or no-go criterion, like the general abundance of suitable building blocks for the desired bioprocess, others affect the economy of the process and hence the price of the resulting product. Changes in the medium composition, which often occur when using a natural resource like lignocellulose, can lead to changes in productivity. For some bioprocesses certain media components will have to be added, for others $\mathrm{pH}$ and temperature have to be controlled and for some even elaborate pretreatment steps for the removal of inhibiting substances have to be performed. All these factors have a significant impact on the economic feasibility of a bioprocess.

Proposed bioprocesses are summed up in the results shown in Tables 5 and 6 . Thermophilic microorganisms have a high potential to 
Citation: Weissgram M, Herwig C, Weber HK (2015) Biotechnological Generation of Value Added Products from Spent Pulping Liquors: Assessing the Potential of Extremophiles. J Bioprocess Biotech 5: 241 doi:10.4172/2155-9821.1000241

Page 10 of 14

\begin{tabular}{|c|c|c|c|c|c|}
\hline Product & Strain & $\underset{\mathrm{Cmol}_{\mathrm{i}}\left(\mathrm{Clmol}_{\mathrm{s}}\right)^{-1}}{\mathbf{Y}_{\mathrm{pls}}}$ & Fermentation conditions & C-Source & References \\
\hline Butanol & $\begin{array}{c}\text { Clostridium } \\
\text { thermosaccharo-lyticum }\end{array}$ & & $58-69^{\circ} \mathrm{C}, \mathrm{pH}$ neutral & starch, glucose & {$[132,168]$} \\
\hline \multirow[t]{2}{*}{ Lactic acid } & $\begin{array}{l}\text { Alkalibacterium } \\
\text { subtropicum }\end{array}$ & & $\begin{array}{c}\mathrm{NaCl} 0-17 \% \text { w/v, } \mathrm{pH} \\
7.5-9.5\end{array}$ & $\begin{array}{l}\text { various carbohydrates, } \\
\text { organic acids }\end{array}$ & [110] \\
\hline & $\begin{array}{l}\text { Marinilactibacillus } \\
\text { psychrotolerans }\end{array}$ & 0.99 & $\begin{array}{c}\mathrm{NaCl} 0-20.5 \% \mathrm{w} / \mathrm{v}, \mathrm{pH} \\
6-10\end{array}$ & glucose & [116] \\
\hline Xylitol & Debaryomyces hansenii & 0.57 & $24^{\circ} \mathrm{C}, \mathrm{pH} 8$ & xylose & [102] \\
\hline \multirow[t]{3}{*}{ PHB } & Haloferax mediderranei & $\begin{array}{c}0.33 \mathrm{~g} \mathrm{~g}^{-1} \\
0.9 \mathrm{~mol} \mathrm{~mol}^{-1}\end{array}$ & $37^{\circ} \mathrm{C}, \mathrm{pH} 7-8$ & $\begin{array}{l}\text { starch } \\
\text { glycerol }\end{array}$ & {$[97,125,126]$} \\
\hline & Halomonas boliviensis & $0.1 \mathrm{~g} \mathrm{~g}^{-1}$ & $\begin{array}{c}\mathrm{NaCl} 0-25 \% \text { w/v } \\
\mathrm{pH} \mathrm{6-11}\end{array}$ & hydrolyzed wheat bran & {$[99,128]$} \\
\hline & Halomonas elongata & & $\begin{array}{l}\mathrm{NaCl} 0-20 \% \text { w/v } \\
\text { pH 5-10; }\end{array}$ & $\begin{array}{c}\text { glucose, mannose, xylose, } \\
\ldots\end{array}$ & {$[99,129]$} \\
\hline
\end{tabular}

Table 5: Microorganisms suitable to produce desirable products from $\mathrm{BL}$.

\begin{tabular}{|c|c|c|c|c|c|}
\hline Product & Strain & $\begin{array}{l}\mathrm{Y}_{\mathrm{pls}} \mathrm{Cmol}_{i} \\
\left(\mathrm{Cmol}_{\mathrm{s}}\right)^{-1}\end{array}$ & Fermentation conditions & C-Source & References \\
\hline \multirow{5}{*}{ Ethanol } & Clostridium thermocellum & 0.347 & $60^{\circ} \mathrm{C}, \mathrm{pH} 5-7$ & cellulose & [164] \\
\hline & & 0.35 & & pretreated wood & [142] \\
\hline & $\begin{array}{c}\text { Clostridium } \\
\text { thermosaccharolyticum }\end{array}$ & 0.26 & $58-69^{\circ} \mathrm{C}, \mathrm{pH} 4.5$ & $\begin{array}{l}\text { oak saw dust hydrolysate } \\
\qquad\left(1 \% \mathrm{H}_{2} \mathrm{SO}_{4}\right)\end{array}$ & [133] \\
\hline & $\begin{array}{c}\text { Thermoanaerobacter } \\
\text { saccharolyticum }\end{array}$ & 0.616 & $50^{\circ} \mathrm{C}, \mathrm{pH} 5,2-5,4$ & xylose & [165] \\
\hline & Thermoanaerobacter mathranii & $\begin{array}{l}0.49 \\
0.55\end{array}$ & $70^{\circ} \mathrm{C}, \mathrm{pH} 4.7-8.8$ & $\begin{array}{l}\text { glucose } \\
\text { xylose }\end{array}$ & {$[156,157]$} \\
\hline & & 0.38 & & wet oxidized wheat straw & [23] \\
\hline \multirow{3}{*}{ Butanol } & $\begin{array}{l}\text { Clostridium saccharoper- } \\
\text { butylacetonicum }\end{array}$ & 0.51 & $30^{\circ} \mathrm{C}, \mathrm{pH} 5.5$ & glucose & [101] \\
\hline & $\begin{array}{c}\text { Clostridium } \\
\text { thermosaccharolyticum }\end{array}$ & & $58-69^{\circ} \mathrm{C}, \mathrm{pH} 4.5$ & $\begin{array}{l}\text { starch, glucose } \\
\text { oak saw dust hydrolysate } \\
\qquad\left(1 \% \mathrm{H}_{2} \mathrm{SO}_{4}\right)\end{array}$ & $\begin{array}{l}{[132]} \\
{[133]}\end{array}$ \\
\hline & Clostridium acetobutylicum & 0.55 & $37^{\circ} \mathrm{C}, \mathrm{pH} 4.3-5$ & glucose & {$[31,83]$} \\
\hline & & 0.23 & & $\begin{array}{l}\mathrm{SO}_{2} \text {-ethaol-water hydrolyzed } \\
\text { spruce }\end{array}$ & [131] \\
\hline Xylitol & Debaryomyces hansenii & $0.507-0.81$ & $24^{\circ} \mathrm{C}, \mathrm{pH} 5.5$ & hydrolyzed brewery waste & {$[25,102]$} \\
\hline \multirow{2}{*}{ Itaconic acid } & A. terreus & 0.26 & pH 2-3.5- & glucose & {$[54]$} \\
\hline & U. maydis & 0.196 & $30^{\circ} \mathrm{C}, \mathrm{pH} 4,5-6$ & glucose & [169] \\
\hline Lactic acid & Bacillus sp. XZL4 & 0.98 & $50^{\circ} \mathrm{C}, 5-6$ & corn stover hydrolysate & [115] \\
\hline Succinic acid & Clostridium thermosuccinogenes & 0.43 & $60^{\circ} \mathrm{C}, \mathrm{pH}$ neutral & inulin & {$[119,120]$} \\
\hline
\end{tabular}

Table 6: Microorganisms suitable to produce desirable products from SSL.

utilize SSL for the production of ethanol, whereas slightly acidophile microorganisms could produce butanol, itaconic acid and xylitol from SSL at acidic $\mathrm{pH}$ values. Itaconic acid is mainly produced by $A$. terreus industrially. This process takes place at low $\mathrm{pH}$ and could utilize the glucose in SSL. However IA production is sensitive to inhibitors in lignocellulose hydrolysate [103]. Therefore, a pretreatment with combined anion and cation exchangers is proposed [104]. A productivity of $2.5 \mathrm{~g} \mathrm{l}^{-1} \mathrm{~h}^{-1}$ is desired, for the process to be economically competitive [1]. Furthermore T. saccharolyticum and C. acetobutylicum are able to ferment sugars from SSL to ethanol and butanol respectively. T. saccharolyticum is capable of fermenting $\mathrm{C} 5$ as well as C6 sugars, which makes this microorganism an attractive opportunity.

The utilization of BL is favored for microorganisms being able to ferment organic acids. Most of these microorganisms transform organic acids to gas. However, there is an additional potential in the utilization of organic acids by mesophile and alkalihalophile microorganisms, leading to innovative products that were not the scope of this publication. Halomonas elongata is promising for the production of xylitol due to its $\mathrm{pH}$-range up to $\mathrm{pH} 10$ and its ability to ferment hemicelluloses.

While a decision which factors are a no-go criterion, and what steps could potentially be performed is a decision that has to be taken for each bioprocess, this publication aims to give the reader an overview on what could be potentially possible and what would be the steps that have to be considered for each individual microorganism, therefore, providing a toolset for the decision making process.

From our own experiments (published and in preparation)we could see that the halophilic production of PHAs and the thermophilic production of EtOH show some promise, but the inhibition phenomena have to be overcome and media have to be designed in way that guarantees maximum compatibility with the pulping processes they are intended for.

However, as several of the proposed strains have been successfully 
Citation: Weissgram M, Herwig C, Weber HK (2015) Biotechnological Generation of Value Added Products from Spent Pulping Liquors: Assessing the Potential of Extremophiles. J Bioprocess Biotech 5: 241 doi:10.4172/2155-9821.1000241

cultivated on various lignocellulosic hydrolysates it could be shown, that extremophiles have some potential for bioprocesses on extreme substrates.

\section{Acknowledgement}

The work was performed within the XpremES project, which was funded by the European Regional Development Fund (EFRE) and the province of Upper Austria.

\section{References}

1. Werpy TA, Holladay JE, White JF (2004) Top value added chemicals from biomass: I. Results of screening for potential candidates from sugars and synthesis gas. Pacific Northwest National Laboratory and the National Renewable Energy Laboratory, Department of Energy, United States, pp: 1-76.

2. The White House (2014) FACT SHEET: President Obama Announces New Actions to Further Strengthen U.S. Manufacturing. Office of the Press Secretary for Immediate Release, Washington, USA.

3. Ramos LP (2003) The chemistry involved in the steam treatment of lignocellulosic materials. Quím Nova 26: 863-871

4. Tran H, Vakkilainnen EK (2007) The Kraft chemical recovery process. Faculty of Applied Science and Engineering, University of Toronto, Toronto, Canada.

5. Pereira SR, Portugal-Nunes DJ, Evtuguin DV, Serafim LS, Xavier AMRB (2013) Advances in ethanol production from hardwood spent sulphite liquors. Process Biochem 48: 272-282

6. Biermann CJ (1996) Introduction and the Literature. In: Biermann CJ (editor) Handbook of pulping and papermaking (Second Edition). Academic Press, San Diego, USA, pp: 1-12.

7. Goodell EG (1930) Process of regenerating black liquors. US 1779537 A.

8. Öhrman O, Häggström C, Wiinikka H, Hedlund J, Gebart R (2012) Analysis of trace components in synthesis gas generated by black liquor gasification. Fuel 102:173-179

9. Nigam JN (2001) Ethanol production from hardwood spent sulfite liquor using an adapted strain of Pichia stipitis. J Ind Microbiol Biotechnol 26: 145-150.

10. Frederick WJ Jr, Lien SJ, Courchene CE, DeMartini NA, Ragauskas AJ, et al. (2008) Production of ethanol from carbohydrates from loblolly pine: a technical and economic assessment. Bioresour Technol 99: 5051-5057.

11. Hučko B, Bampidis V, Kodeš A, Christodoulou V, Mudřik Z, et al. (2009) Rumen fermentation characteristics in pre-weaning calves receiving yeast culture supplements. Czech J Anim Sci 54: 435-442

12. Hocking MB (1997) Vanillin: Synthetic flavoring from spent sulfite liquor. J Chem Educ 74: 1055.

13. Niemelä K, Tamminen T, Ohra-aho T (2007) Black liquor components as potential raw materials. In: TAPPSA, Durban, South Africa.

14. Alriksson B, Sjöde A, Nilvebrant NO, Jönsson LJ (2006) Optimal conditions for alkaline detoxification of dilute-acid lignocellulose hydrolysates. Appl Biochem Biotechnol 129-132: 599-611.

15. Mills TY, Sandoval NR, Gill RT (2009) Cellulosic hydrolysate toxicity and tolerance mechanisms in Escherichia coli. Biotechnol Biofuels 2: 26.

16. Olsson L, Hahn-Hägerdal B (1996) Fermentation of lignocellulosic hydrolysates for ethanol production. Enzyme Microb Tech 18:312-331.

17. Larsson S, Quintana-Sáinz A, Reimann A, Nilvebrant NO, Jönsson LJ (2000) Influence of lignocellulose-derived aromatic compounds on oxygen-limited growth and ethanolic fermentation by Saccharomyces cerevisiae. Appl Biochem Biotechnol 84-86: 617-32.

18. Zaldivar J, Nielsen J, Olsson L (2001) Fuel ethanol production from lignocellulose: a challenge for metabolic engineering and process integration. Appl Microbiol Biotechnol 56: 17-34.

19. Martinez A, Rodriguez ME, Wells ML, York SW, Preston JF, et al. (2001) Detoxification of dilute acid hydrolysates of lignocellulose with lime. Biotechnol Prog 17: 287-293.

20. Keweloh H, Weyrauch G, Rehm HJ (1990) Phenol-induced membrane changes in free and immobilized Escherichia coli. Appl Microbiol Biotechnol 33: 66-71.

21. Helle S, Cameron D, Lam J, White B, Duff S (2003) Effect of inhibitory compounds found in biomass hydrolysates on growth and xylose fermentation by a genetically engineered strain of $S$. cerevisiae. Enzyme Microb Technol 33: 786-792

22. Ezeji T, Qureshi N, Blaschek HP (2007) Butanol production from agricultura residues: Impact of degradation products on Clostridium beijerinckii growth and butanol fermentation. Biotechnol Bioeng 97: 1460-1469.

23. Klinke HB, Thomsen AB, Ahring BK (2001) Potential inhibitors from wet oxidation of wheat straw and their effect on growth and ethanol production by Thermoanaerobacter mathranii. Appl Microbiol Biotechnol 57: 631-638.

24. Mussatto SI, Roberto IC (2004) Alternatives for detoxification of diluted-acid lignocellulosic hydrolyzates for use in fermentative processes: a review. Bioresour Technol 93: 1-10.

25. Carvalheiro F, Duarte LC, Lopes S, Parajó JC, Pereira H, et al. (2005) Evaluation of the detoxification of brewery's spent grain hydrolysate for xylito production by Debaryomyces hansenii CCMI 941. Process Biochem 40: 12151223.

26. Qureshi N, Ezeji TC, Ebener J, Dien BS, Cotta MA, et al. (2008) Butano production by Clostridium beijerinckii. Part I: use of acid and enzyme hydrolyzed corn fiber. Bioresour Technol 99: 5915-5922.

27. Qureshi N, Saha BC, Hector RE, Cotta MA (2008) Removal of fermentation inhibitors from alkaline peroxide pretreated and enzymatically hydrolyzed wheat straw: Production of butanol from hydrolysate using Clostridium beijerinckii in batch reactors. Biomass Bioenerg 32: 1353-1358.

28. Restolho JA, Prates A, de Pinho MN, Afonso MD (2009) Sugars and lignosulphonates recovery from eucalyptus spent sulphite liquor by membrane processes. Biomass Bioenerg 33: 1558-1566.

29. Martín C, Marcet M, Almazán O, Jönsson LJ (2007) Adaptation of a recombinant xylose-utilizing Saccharomyces cerevisiae strain to a sugarcane bagasse hydrolysate with high content of fermentation inhibitors. Biores Technol 98 1767-1773.

30. Pereira SR, Sànchez I Nogué V, Frazão CJ, Serafim LS, Gorwa-Grauslund MF et al. (2015) Adaptation of Scheffersomyces stipitis to hardwood spent sulfite liquor by evolutionary engineering. Biotechnol Biofuels 8: 50 .

31. Dusséaux S, Croux C, Soucaille P, Meynial-Salles I (2013) Metabolic engineering of Clostridium acetobutylicum ATCC 824 for the high-yield production of a biofuel composed of an isopropanol/butanol/ethanol mixture. Metab Eng 18: 1-8

32. Hahn-Hägerdal B, Karhumaa K, Jeppsson M, Gorwa-Grauslund MF (2007) Metabolic engineering for pentose utilization in Saccharomyces cerevisiae. Adv Biochem Eng Biotechnol 108: 147-177.

33. Kevbrin V, Romanek CS, Wiegel J (2003) Alkalithermophiles: A double challenge from extreme environments. In: Seckbach J (ed) Cellular Origin, Life in Extreme Habitats and Astrobiology 6: 395-412.

34. Freund A (1881) Über die Bildung und Darstellung von Trimethylenalkohol aus Glycerin. Monatsh Chem 2: 636-641.

35. Elsden SR (1938) The effect of $\mathrm{CO}(2)$ on the production of succinic acid by Bact. coli commune. Biochem J 32: 187-193.

36. Kumar V, Ashok S, Park S (2013) Recent advances in biological production of 3-hydroxypropionic acid. Biotechnol Adv 31: 945-961.

37. Leja K, Czaczyk K, Myszka K (2011) Biotechnological synthesis of 1,3-propanediol using Clostridium ssp. Afr J Biotechnol 10: 11093-11101.

38. Nakas JP, Schaedle M, Parkinson CM, Coonley CE, Tanenbaum SW (1983) System development for linked-fermentation production of solvents from algal biomass. Appl Environ Microbiol 46: 1017-1023.

39. Chatzifragkou A, Papanikolaou S, Dietz D, Doulgeraki AI, Nychas GJ, et al. (2011) Production of ,3-propanediol by Clostridium butyricum growing on biodiesel-derived crude glycerol through a non-sterilized fermentation process Appl Microbiol Biotechnol 91: 101-112.

40. Talarico TL, Axelsson LT, Novotny J, Fiuzat M, Dobrogosz WJ (1990) Utilization of Glycerol as a Hydrogen Acceptor by Lactobacillus reuteri: Purification of ,3-Propanediol:NAD Oxidoreductase. Appl Environ Microbiol 56: 943-948.

41. Kurian J (2005) A New Polymer Platform for the Future-Sorona ${ }^{\circledR}$ from Corn Derived 1,3-Propanediol. J Polym Environ 13: 159-167.

42. Nanninga HJ, Gottschal JC (1987) Properties of Desulfovibrio carbinolicus sp. nov. and Other Sulfate-Reducing Bacteria Isolated from an Anaerobic- 
Citation: Weissgram M, Herwig C, Weber HK (2015) Biotechnological Generation of Value Added Products from Spent Pulping Liquors: Assessing the Potential of Extremophiles. J Bioprocess Biotech 5: 241 doi:10.4172/2155-9821.1000241

Purification Plant. Appl Environ Microbiol 53: 802-809.

43. Qatibi Al, Bennisse R, Jana M, Garcia JL (1998) Anaerobic degradation of glycerol by Desulfovibrio fructosovorans and $D$. carbinolicus and evidence for glycerol-dependent utilization of 1,2-propanediol. Curr Microbiol 36: 283-290.

44. McGarvey GJ, Williams JM, Hiner RN, Matsubara Y, Oh T (1986) L-Aspartic acid in acyclic stereoselective synthesis. Synthetic studies on amphotericin B. J Am Chem Soc 108: 4943-4952.

45. Liu XP, Zheng TL (2014) The Synthesis of a Polyaspartic Acid Ester and Development of the Coatings. Adv Mat Res 842: 297-301.

46. Umemura I, Takamatsu S, Sato T, Tosa T, Chibata I (1984) Improvement of production of I-aspartic acid using immobilized microbial cells. Appl Microbiol Biotechnol 20: 291-295

47. Kawabata N, Hatanaka H, Odaka H (1995) Continuous production of I-aspartic acid from ammonium fumarate using immobilized cells by capture on the surface of nonwoven cloth coated with a pyridinium-type polymer. J Ferment Bioeng 79: 317-322.

48. Roa Engel CA, Straathof AJ, Zijlmans TW, van Gulik WM, van der Wielen LA (2008) Fumaric acid production by fermentation. Appl Microbiol Biotechnol 78 379-389.

49. Goldberg I, Rokem JS, Pines O (2006) Organic acids: old metabolites, new themes. J Chem Technol Biotechnol 81: 1601-1611.

50. Rhodes RA, Lagoda AA, Misenheimer TJ, Smith ML, Anderson RF, et al. (1962) Production of Fumaric Acid in 20-Liter Fermentors. Appl Microbiol 10: 9-15.

51. Gu C, Zhou Y, Liu L, Tan T, Deng L (2013) Production of fumaric acid by immobilized Rhizopus arrhizus on net. Bioresour Technol 131: 303-307.

52. Kim JW, Peeples TL (2006) Screening extremophiles for bioconversion potentials. Biotechnol Prog 22: 1720-1724.

53. Willke T, Vorlop KD (2001) Biotechnological production of itaconic acid. App Microbiol Biotechnol 56: 289-295.

54. Tevz G, Bencina M, Legisa M (2010) Enhancing itaconic acid production by Aspergillus terreus. Appl Microbiol Biotechnol 87: 1657-1664.

55. Koller M, Salerno A, Dias M, Reiterer A, Braunegg G (2010) Modern Biotechnological polymer synthesis: a review. Food Technol Biotechnol 48: 255-269.

56. Narayanan N, Roychoudhury PK, Srivastava A (2004) L (+) lactic acid fermentation and its product polymerization. Electron J Biotechnol 7: 167-178.

57. Garde A, Jonsson G, Schmidt AS, Ahring BK (2002) Lactic acid production from wheat straw hemicellulose hydrolysate by Lactobacillus pentosus and Lactobacillus brevis. Bioresour Technol 81: 217-223.

58. Kidwell H (2008) Bio-Succinic acid to go commercial. Biopharma-Reporter com.

59. Tan JP, Md. Jahim J, Wu TY, Harun S, Kim BH, et al. (2014) Insight into biomass as a renewable carbon source for the production of succinic acid and the factors affecting the metabolic flux toward higher succinate yield. Ind Eng Chem Res 53: 16123-16134.

60. Beauprez JJ, De Mey M, Soetaert WK (2010) Microbial succinic acid production: Natural versus metabolic engineered producers. Process Biochem 45: $1103-1114$

61. Zeikus JG, Jain MK, Elankovan P (1999) Biotechnology of succinic acid production and markets for derived industrial products. Appl Microbiol Biotechnol 51: 545-552.

62. Bugnicourt E, Cinelli P, Lazzeri A, Alvarez V (2014) Polyhydroxyalkanoate (PHA): Review of synthesis, characteristics, processing and potential applications in packaging. Express Polym Lett 8: 791-808.

63. Duncan SH, Louis P, Flint HJ (2004) Lactate-utilizing bacteria, isolated from human feces, that produce butyrate as a major fermentation product. Appl Environ Microbiol 70: 5810-5817.

64. http://ethanolrfa.org/page/-/PDFs/RFA 2013 Ethanol Industry Outlook. pdf?nocdn $=1$

65. Gírio FM, Fonseca C, Carvalheiro F, Duarte LC, Marques S, et al. (2010) Hemicelluloses for fuel ethanol: A review. Bioresour Technol 101: 4775-4800.

66. Koppram R, Tomás-Pejó E, Xiros C, Olsson L (2014) Lignocellulosic ethanol production at high-gravity: challenges and perspectives. Trends Biotechnol 32 46-53

67. Görgens J, Carrier M, García-Aparicio M (2014) Biomass Conversion to Bioenergy Products. In: Seifert T (ed) Bioenergy from Wood. Springer Netherlands, 26: 137-167.

68. Wiegel J (1980) Formation of ethanol by bacteria. A pledge for the use of extreme thermophilic anaerobic bacteria in industrial ethanol fermentation processes. Experientia 36: 1434-1446.

69. Olson DG, Sparling R, Lynd LR (2015) Ethanol production by engineered thermophiles. Curr Opin Biotechnol 33: 130-141.

70. Jonas R, Silveira MM (2004) Sorbitol can be produced not only chemically but also biotechnologically. Appl Biochem Biotechnol 118: 321-336.

71. Zhao L, Zhou JH, Sui ZJ, Zhou XG (2010) Hydrogenolysis of sorbitol to glycols over carbon nanofiber supported ruthenium catalyst. Chem Eng Sci 65: 30-35.

72. Vieira MGA, da Silva MA, dos Santos LO, Beppu MM (2011) Natural-based plasticizers and biopolymer films: A review. Eur Polym J 47:254-263

73. Yin X, Duan H, Wang X, Sun L, Sun W, et al. (2014) An investigation on synthesis of alkyd resin with sorbitol. Prog Org Coat 77: 674-678.

74. Transparency Market Research (2013) Global Sorbitol Market - Isosorbide, Propylene Glycol, Glycerol \& Other Downstream Opportunities, Applications (Toothpaste, Vitamin C, Sweetener Etc.), Size, Share, Growth, Trends And Forecast, 2012 - 2018. Transparency Market research, Albany, New York USA.

75. Silveira MM, Jonas R (2002) The biotechnological production of sorbitol. Appl Microbiol Biotechnol 59: 400-408.

76. Barrow KD, Collins JG, Leight DA, Rogers PL, Warr RG (1984) Sorbitol production by Zymomonas mobilis. Appl Microbiol Biotechnol 20: 225-232.

77. Vongsuvanlert V, Tani Y (1988) Characterization of D-sorbitol dehydrogenase involved in D-sorbitol production of a methanol yeast, Candida boidinii (Kloeckera sp.) No. 2201. Agri Biol Chem 52: 419-426.

78. Sasahara H, Izumori KEN (1994) Reduction of L-sorbose by halotolerant yeast Candida famata 234B. Seibutsu-kogaku Kaishi 72: 299-304.

79. Granström TB, Izumori K, Leisola M (2007) A rare sugar xylitol. Part II biotechnological production and future applications of xylitol. Appl Microbio Biotechnol 74: 273-276.

80. Ravella S, Gallagher J, Fish S, Prakasham R (2012) Overview on Commercia Production of Xylitol, Economic Analysis and Market Trends. In: da Silva SS Chandel AK (eds) D-Xylitol. Springer Berlin Heidelberg, pp: 291-306.

81. Onishi H, Suzuki T (1969) Microbial production of xylitol from glucose. App Microbiol 18: 1031-1035

82. Misra S, Raghuwanshi S, Saxena RK (2012) Fermentation behavior of an osmotolerant yeast $D$. hansenii for Xylitol production. Biotechnol Prog 28 1457-1465.

83. Bahl H, Andersch W, Braun K, Gottschalk G (1982) Effect of pH and butyrate concentration on the production of acetone and butanol by Clostridium acetobutylicum grown in continuous culture. Europ J Appl Microbiol Biotechnol 14: $17-20$

84. Monot F, Engasser JM, Petitdemange $\mathrm{H}$ (1984) Influence of $\mathrm{pH}$ and undissociated butyric acid on the production of acetone and butanol in batch cultures of Clostridium acetobutylicum. Appl Microbiol Biotechnol 19: 422-426.

85. Potvin J, Desrochers M, Arcand Y (1988) Fermentation of kraft black liquor for the production of citric acid by Candida tropicalis. Appl Microbiol Biotechnol 28: $350-355$

86. Palmqvist E, Hahn-Hägerdal B (2000) Fermentation of lignocellulosic hydrolysates. II: inhibitors and mechanisms of inhibition. Biores Technol 74 25-33.

87. Lorantfy B, Seyer B, Herwig C (2014) Stoichiometric and kinetic analysis of extreme halophilic Archaea on various substrates in a corrosion resistant bioreactor. N Biotechnol 31: 80-89.

88. Holzapfel WH, Wood BJB, Ishikawa M, Yamasato K (2014) The genus Marinilactibacillus. Lactic Acid Bacteria: Biodiversity and Taxonomy. John Wiley \& Sons, Ltd, pp: 125-134. 
Citation: Weissgram M, Herwig C, Weber HK (2015) Biotechnological Generation of Value Added Products from Spent Pulping Liquors: Assessing the Potential of Extremophiles. J Bioprocess Biotech 5: 241 doi:10.4172/2155-9821.1000241

89. Parekh SR, Pandey NK (1985) Production of glycerol by hansenula anomala. Biotechnol Bioeng 27: 1089-1091.

90. Oren A (1995) Uptake and turnover of acetate in hypersaline environments. FEMS Microbiol Ecol 18: 75-84.

91. Bräsen C, Schönheit P (2001) Mechanisms of acetate formation and acetate activation in halophilic archaea. Arch Microbiol 175: 360-368.

92. Oren A, Gurevich P (1995) Diversity of lactate metabolism in halophilic archaea. Can J Microbiol 41: 302-307.

93. Carrasco IJ, Márquez MC, Xue Y, Ma Y, Cowan DA, et al. (2007) Bacillus chagannorensis sp. nov., a moderate halophile from a soda lake in Inner Mongolia, China. Int J Syst Evol Microbiol 57: 2084-2088.

94. Tsu II, Huang C, Garcia J, Patel BKC, Cayol JL, et al. (1998) Isolation and characterization of Desulfovibrio senezii sp. nov., A halotolerant sulfate reducer from a solar saltern and phylogenetic confirmation of desulfovibrio fructosovorans as a new species Arch Microbiol 170: 313-317.

95. Cuadros-Orellana S, Pohlschröder M, Durrant LR (2006) Isolation and characterization of halophilic archaea able to grow in aromatic compounds. Int Biodeter Biodegr 57: 151-154.

96. Quillaguaman J, Delgado O, Mattiasson B, Hatti-Kaul R (2006) Poly(betahydroxybutyrate) production by a moderate halophile, Halomonas boliviensis LC1. Enzyme Microb Technol 38: 148-154.

97. Tekin E, Ates M, Kahraman Ö (2012) Poly-3-hydroxybutyrate-producing extreme halophilic archaeon: Haloferax sp. MA10 isolated from Camalt। Saltern, Izmir. Turk J Biol 36: 303-312.

98. Galinski EA (1993) Compatible solutes of halophilic eubacteria: molecula principles, water-solute interaction, stress protection. Experientia 49: 487-496.

99. Van TD (2009) Production of poly(3-hydroxybutyrate) and ectoines using a halophilic bacterium. Department of Biotechnology. Lund University, Lund, pp: 145.

100. Weissgram M, Gstöttner J, Lorantfy B, Tenhaken R, Herwig C, et al. (2015) Generation of PHB from spent sulfite liquor using halophilic microorganisms. Microorganisms 3: 268-289.

101. Tashiro Y, Takeda K, Kobayashi G, Sonomoto K, Ishizaki A, et al. (2004) High butanol production by Clostridium saccharoperbutylacetonicum N1-4 in fed-batch culture with $\mathrm{pH}$-Stat continuous butyric acid and glucose feeding method. J Biosci Bioeng 98: 263-268.

102. Converti A, Domínguez JM (2001) Influence of temperature and pH on xylito production from xylose by Debaryomyces hansenii. Biotechnol Bioeng 75 $39-45$

103. Okabe M, Lies D, Kanamasa S, Park EY (2009) Biotechnological production of itaconic acid and its biosynthesis in Aspergillus terreus. Appl Microbiol Biotechnol 84: 597-606.

104. Kobayashi T, Nakamura I, Nakagawa M (1975) Process for producing itaconic acid. Google Patents US3873425 A.

105. Koch G (2008) Raw Material for Pulp. Handbook of Pulp. Wiley-VCH Verlag $\mathrm{GmbH}, \mathrm{pp}: 21-68$.

106. Sjöström E (1993) Wood chemistry: fundamentals and applications, 2nd edn Academic Press, San Diego, California, USA.

107. Rydholm SA (1965) Pulping processes. Interscience Publishers, New York USA.

108. Biebl H, Menzel K, Zeng AP, Deckwer WD (1999) Microbial production of ,3-propanediol. Appl Microbiol Biotechnol 52: 289-297.

109. Doleyres Y, Beck P, Vollenweider S, Lacroix C (2005) Production of 3-hydroxypropionaldehyde using a two-step process with Lactobacillus reuteri. Appl Microbiol Biotechnol 68: 467-474

110. Ishikawa M, Nakajima K, Ishizaki S, Kodama K, Okamoto-Kainuma A, et al. (2011) Alkalibacterium subtropicum sp. nov., a slightly halophilic and alkaliphilic marine lactic acid bacterium isolated from decaying marine algae. Int J Syst Evol Microbiol 61: 2996-3002.

111. Ishikawa M, Yamasato K, Kodama K, Yasuda H, Matsuyama M, et al. (2013) Alkalibacterium gilvum sp. nov., slightly halophilic and alkaliphilic lactic acid bacterium isolated from soft and semi-hard cheeses. Int J Syst Evol Microbio 63: $1471-1478$
112. Moon TS, Dueber JE, Shiue E, Prather KL (2010) Use of modular, synthetic scaffolds for improved production of glucaric acid in engineered $E$. coli. Metab Eng 12: 298-305.

113. Yahiro K, Takahama T, Park YS, Okabe M (1995) Breeding of Aspergillus terreus mutant TN-484 for itaconic acid production with high yield. J Ferment Bioeng 79: 506-508

114. Patel M, Ou M, Ingram L, Shanmugam K (2004) Fermentation of sugar cane bagasse hemicellulose hydrolysate to $\mathrm{L}-(+)$-lactic acid by a thermotolerant acidophilic Bacillus sp. Biotechnol Lett 26: 865-868.

115. Xue Z, Wang L, Ju J, Yu B, Xu P, et al. (2012) Efficient production of polymergrade L-lactic acid from corn stover hydrolyzate by thermophilic Bacillus $\mathrm{sp}$ strain XZL4. Springerplus 1: 43.

116. Ishikawa M, Nakajima K, Yanagi M, Yamamoto $Y$, Yamasato K (2003) Marinilactibacillus psychrotolerans gen. nov., sp. nov., a halophilic and alkaliphilic marine lactic acid bacterium isolated from marine organisms in temperate and subtropical areas of Japan. Int J Syst Evol Microbiol 53: 711 720.

117. Guettler MV, Rumler D, Jain MK (1999) Actinobacillus succinogenes sp. nov., a novel succinic-acid-producing strain from the bovine rumen. Int J Syst Bacteriol 49 Pt 1: 207-216.

118. Wan C, Li Y, Shahbazi A, Xiu S (2008) Succinic acid production from cheese whey using Actinobacillus succinogenes 130 Z. Appl Biochem Biotechnol 145: $111-119$

119. Drent WJ, Lahpor GA, Wiegant WM, Gottschal JC (1991) Fermentation of Inulin by Clostridium thermosuccinogenes sp. nov., a Thermophilic Anaerobic Bacterium Isolated from Various Habitats. Appl Environ Microbiol 57: 455-462

120. Sridhar J, Eiteman MA, Wiegel JW (2000) Elucidation of enzymes in fermentation pathways used by Clostridium thermosuccinogenes growing on inulin. Appl Environ Microbiol 66: 246-251.

121. Brigham CJ, Kurosawa K, Rha C, Sinskey AJ (2011) Bacterial carbon storage to value added products. J Microbial Biochem Technol S3: 002.

122. Huschner F, Grousseau E, Brigham CJ, Plassmeier J, Popovic M, et al (2015) Development of a feeding strategy for high cell and PHA density fedbatch fermentation of Ralstonia eutropha $\mathrm{H} 16$ from organic acids and their salts. Process Biochem 50: 165-172.

123. Riedel SL, Bader J, Brigham CJ, Budde CF, Yusof ZA, et al. (2012) Production of poly(3-hydroxybutyrate-co-3-hydroxyhexanoate) by Ralstonia eutropha in high cell density palm oil fermentations. Biotechnol Bioeng 109: 74-83.

124. Kahar P, Tsuge T, Taguchi K, Doi $Y$ (2004) High yield production of polyhydroxyalkanoates from soybean oil by Ralstonia eutropha and its recombinant strain. Polym Degrad Stabil 83: 79-86.

125. Lu Q, Han J, Zhou L, Zhou J, Xiang H (2008) Genetic and biochemical characterization of the poly(3-hydroxybutyrate-co-3-hydroxyvalerate) synthase in Haloferax mediterranei. J Bacteriol 190: 4173-4180.

126. Hermann-Krauss C, Koller M, Muhr A, Fasl H, Stelzer F, et al. (2013) Archaeal production of polyhydroxyalkanoate (PHA) co- and terpolyesters from biodiesel industry-derived by-products. Archaea 2013: 129268.

127. Koller M (2015) Recycling of waste streams of the biotechnological Poly(hydroxyalkanoate) production by Haloferax mediterranei on whey. In J Polym Sci 2015: 1-8.

128. Van-Thuoc D, Quillaguamán J, Mamo G, Mattiasson B (2008) Utilization of agricultural residues for poly(3-hydroxybutyrate) production by Halomonas boliviensis LC1. J Appl Microbiol 104: 420-428.

129. Mata JA, Martínez-Cánovas J, Quesada E, Béjar V (2002) A detailed phenotypic characterisation of the type strains of Halomonas species. Syst Appl Microbiol 25: 360-375.

130. Mothes G, Schubert T, Harms H, Maskow T (2008) Biotechnological coproduction of compatible solutes and polyhydroxyalkanoates using the genus Halomonas. Eng Life Sci 8: 658-662.

131. Survase SA, Sklavounos E, Jurgens G, van Heiningen A, Granström $T$ (2011) Continuous acetone-butanol-ethanol fermentation using $\mathrm{SO}_{2}$-ethanolwater spent liquor from spruce. Bioresour Technol 102: 10996-11002.

132. Freier-Schröder D, Wiegel J, Gottschalk G (1989) Butanol formation by Clostridium thermosaccharolyticum at neutral $\mathrm{pH}$. Biotechnol Lett 11: 831 
Citation: Weissgram M, Herwig C, Weber HK (2015) Biotechnological Generation of Value Added Products from Spent Pulping Liquors: Assessing the Potential of Extremophiles. J Bioprocess Biotech 5: 241 doi:10.4172/2155-9821.1000241

836

133. Liu HS, Hsu HW, Sayler GS (1988) Bioconversion of D-Xylose and pretreated oak sawdust to ethanol using Clostridium thermosacchrolyticum by batch and continuous up-flow reactors. Biotechnol Progr 4: 40-46.

134. Pley U, Schipka J, Gambacorta A, Jannasch HW, Fricke H, et al. (1991) Pyrodictium abyssi sp. nov. Represents a novel heterotrophic marine archaeal hyperthermophile growing at $110^{\circ} \mathrm{C}$. Syst Appl Microbiol 14: 245253

135. Børresen BT, Kotlar HK (2013) Alkanol. Google Patents. US20130059354 A1.

136. Svetlitchnyi VA, Kensch O, Falkenhan DA, Korseska SG, Lippert N, et al. (2013) Single-step ethanol production from lignocellulose using nove extremely thermophilic bacteria. Biotechnol Biofuels 6: 31 .

137. Crespo C, Pozzo T, Karlsson EN, Alvarez MT, Mattiasson B (2012) Caloramator boliviensis sp. nov., a thermophilic, ethanol-producing bacterium isolated from a hot spring. Int J Syst Evol Microbiol 62: 1679-1686.

138. Crespo CF, Badshah M, Alvarez MT, Mattiasson B (2012) Ethanol production by continuous fermentation of $\mathrm{D}-(+)$-cellobiose, $\mathrm{D}-(+)$-xylose and sugarcane bagasse hydrolysate using the thermoanaerobe Caloramator boliviensis. Bioresour Technol 103: 186-191.

139. Sato K, Tomita M, Yonemura S, Goto S, Sekine K, et al. (1993) Characterization of and ethanol hyper-production by Clostridium thermocellum I-1-B. Biosci Biotechnol Biochem 57: 2116-2121.

140. Parsons RV, Agbor VB, Lam J, Levin DB, Cenkowski S (2013) Fermentative production of ethanol and hydrogen from flax shive by Clostridium thermocellum after pretreatment using sodium ethoxide and aqueous sodium hydroxide. The Canadian Society for Bioengineering. CSBE/ SCGAB 2013 Annual Conference University of Saskatechewan, Saskatoon Saskatchewan

141. Balusu R, Paduru RM, Seenayya G, Reddy G (2004) Production of ethano from cellulosic biomass by Clostridium thermocellum SS19 in submerged fermentation: screening of nutrients using Plackett-Burman design. Appl Biochem Biotechnol 117: 133-141.

142. Lynd LR, Grethlein HE, Wolkin RH (1989) Fermentation of Cellulosic Substrates in Batch and Continuous Culture by Clostridium thermocellum. Appl Environ Microbiol 55: 3131-3139.

143. San Martin R, Bushell D, Leak DJ, Hartley BS (1992) Development of a synthetic medium for continuous anaerobic growth and ethanol production with a lactate dehydrogenase mutant of Bacillus stearothermophilus. J Gen Microbiol 138: 987-996.

144. Nazina TN, Tourova TP, Poltaraus AB, Novikova EV, Grigoryan AA, et al. (2001) Taxonomic study of aerobic thermophilic bacilli: descriptions of Geobacillus subterraneus gen. nov., sp. nov. and Geobacillus uzenensis sp. nov. from petroleum reservoirs and transfer of Bacillus stearothermophilus, Bacillus thermocatenulatus, Bacillus thermoleovorans, Bacillus kaustophilus, Bacillus thermodenitrificans to Geobacillus as the new combinations $G$. stearothermophilus, G. th. Int J Syst Evol Microbiol 51: 433-446.

145. Payton MA (1984) Production of ethanol by thermophilic bacteria. Trends Biotechnol 2: 153-158.

146. Suzuki Y, Kishigami T, Inoue K, Mizoguchi Y, Eto N, et al. (1983) Bacillus thermoglucosidasius sp. nov., a New Species of Obligately Thermophilic Bacilli. Syst Appl Microbiol 4: 487-495

147. Cripps RE, Eley K, Leak DJ, Rudd B, Taylor M, et al. (2009) Metabolic engineering of Geobacillus thermoglucosidasius for high yield ethanol production. Metab Eng 11: 398-408.

148. Brynjarsdottir H, Wawiernia B, Orlygsson J (2012) Ethanol Production from Sugars and Complex Biomass by Thermoanaerobacter AK5: The Effect of Electron-Scavenging Systems on End-Product Formation. Energy Fuel 26 4568-4574.

149. Zeikus JG, Hegge PW, Anderson M (1979) Thermoanaerobium brockil gen. nov. and sp. nov., a new chemoorganotrophic, caldoactive, anaerobic bacterium. Arch Microbiol 122: 41-48.

150. Ben-Bassat A, Lamed R, Zeikus JG (1981) Ethanol production by thermophilic bacteria: metabolic control of end product formation in Thermoanaerobium brockii. J Bacteriol 146: 192-199.
151. Wiegel J, Ljungdahl LG (1981) Thermoanaerobacter ethanolicus; gen. nov spec. nov., a new, extreme thermophilic, anaerobic bacterium. Arch Microbio 128: 343-348.

152. Carreira LH, Wiegel J, Ljungdahl LG (1983) Production of ethanol from biopolymers by anaerobic, thermophilic, and extreme thermophilic bacteria. I. Regulation of carbohydrate utilization in mutants of Thermoanaerobacter ethanolicus. Biotechnol. Bioeng 13: 183-191.

153. Lacis L, Lawford $\mathrm{H}$ (1988) Ethanol production from xylose by Thermoanaerobacter ethanolicus in batch and continuous culture. Arch Microbiol 150: 48-55

154. Wiegel J, Carreira LH, Mothershed CP, Puls J (1983) Production of ethano from biopolymers by anaerobic, thermophilic, and extreme thermophilic bacteria. II. Thermoanaerobacter ethanolicus JW200 and its mutants in batch cultures and resting cell experiments. Biotechol Bioeng Symp 13: 193-205.

155. Avci A, Dönmez S (2006) Effect of zinc on ethanol production by two Thermoanaerobacter strains. Process Biochem 41: 984-989.

156. Larsen L, Nielsen P, Ahring BK (1997) Thermoanaerobacter mathranii sp. nov., an ethanol-producing, extremely thermophilic anaerobic bacterium from a hot spring in Iceland. Arch Microbiol 168: 114-119.

157. Yao S, Mikkelsen MJ (2010) Metabolic engineering to improve ethanol production in Thermoanaerobacter mathranii. Appl Microbiol Biotechnol 88 : 199-208.

158. Georgieva TI, Ahring BK (2007) Evaluation of continuous ethanol fermentation of dilute-acid corn stover hydrolysate using thermophilic anaerobic bacterium Thermoanaerobacter BG1L1. Appl Microbiol Biotechnol 77: 61-68.

159. Georgieva TI1, Mikkelsen MJ, Ahring BK (2008) Ethanol production from wet-exploded wheat straw hydrolysate by thermophilic anaerobic bacterium Thermoanaerobacter BG1L1 in a continuous immobilized reactor. Appl Biochem Biotechnol 145: 99-110.

160. Ahring BK, Licht D, Schmidt AS, Sommer P, Thomsen AB (1999) Production of ethanol from wet oxidised wheat straw by Thermoanaerobacter mathranii. Bioresour Technol 68: 3-9.

161. Ng TK, Ben-Bassat A, Zeikus JG (1981) Ethanol production by thermophilic bacteria: fermentation of cellulosic substrates by cocultures of Clostridium thermocellum and Clostridium thermohydrosulfuricum. Appl Environ Microb 41: 1337-1343.

162. Lovitt RW, Longin R, Zeikus JG (1984) Ethanol Production by Thermophilic Bacteria: Physiological Comparison of Solvent Effects on Parent and Alcohol-Tolerant Strains of Clostridium thermohydrosulfuricum. Appl Environ Microbiol 48: 171-177.

163. Lovitt RW, Shen GJ, Zeikus JG (1988) Ethanol production by thermophilic bacteria: biochemical basis for ethanol and hydrogen tolerance in Clostridium thermohydrosulfuricum. J Bacteriol 170: 2809-2815.

164. Jiang HL, He Q, He Z, Hemme CL, Wu L, et al. (2013) Continuous cellulosic bioethanol fermentation by cyclic fed-batch cocultivation. Appl Environ Microbiol 79: 1580-1589.

165. Shaw AJ, Podkaminer KK, Desai SG, Bardsley JS, Rogers SR, et al. (2008) Metabolic engineering of a thermophilic bacterium to produce ethanol at high yield. Proc Natl Acad Sci U S A 105: 13769-13774.

166. Felipe MG, Vieira DC, Vitolo M, Silva SS, Roberto IC, et al. (1995) Effect of acetic acid on xylose fermentation to xylitol by Candida quilliermondii. J Basic Microbiol 35: 171-177.

167. Suzuki S, Sugiyama M, Mihara Y, Hashiguchi K, Yokozeki K (2002) Novel enzymatic method for the production of xylitol from D-arabitol by Gluconobacter oxydans. Biosci Biotechnol Biochem 66: 2614-2620.

168. Wiegel J, Mothershed CP, Puls J (1985) Differences in Xylan Degradation by Various Noncellulolytic Thermophilic anaerobes and Clostridium thermocellum. Appl Environ Microbiol 49: 656-659.

169. Klement T, Milker S, Jäger G, Grande PM, Domínguez de María P, et al. (2012) Biomass pretreatment affects Ustilago maydis in producing itaconic acid. Microb Cell Fact 11: 43 